\title{
CALIFORNIA POWER PLANT SITING STUDY
}

\author{
Executive Summary \\ Volume I
}

\author{
Prepared for \\ RESOURCES AGENCY \\ STATE OF CALIFORNIA \\ Contract No. 30-22 \\ and
}

U. S. ATOMIC ENERGY COMMISSION

May, 1973

This document is

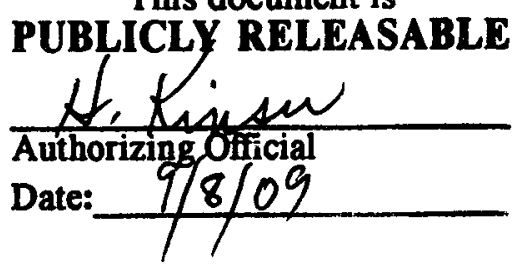

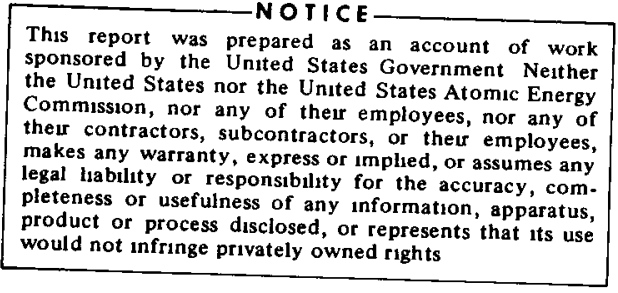

This report was prepared as an account of work sponsored by the United States Government Netther their makes any wars, subcontractors, or theur employees, legal hability or responsibilty for the accuracy, com preness or usefulness of any information, apparatus, or process disclosed, or represents that its use

\section{HOLMES \& NARVER, INC.}

Anaheım, Calıfornı

In Association With

\section{DAMES \& MOORE}

Los Angeles, Calıfornıa 


\section{DISCLAIMER}

This report was prepared as an account of work sponsored by an agency of the United States Government. Neither the United States Government nor any agency Thereof, nor any of their employees, makes any warranty, express or implied, or assumes any legal liability or responsibility for the accuracy, completeness, or usefulness of any information, apparatus, product, or process disclosed, or represents that its use would not infringe privately owned rights. Reference herein to any specific commercial product, process, or service by trade name, trademark, manufacturer, or otherwise does not necessarily constitute or imply its endorsement, recommendation, or favoring by the United States Government or any agency thereof. The views and opinions of authors expressed herein do not necessarily state or reflect those of the United States Government or any agency thereof. 


\section{DISCLAIMER}

Portions of this document may be illegible in electronic image products. Images are produced from the best available original document. 


\section{TABLE OF CONTENTS}

Section

$\underline{\text { Page }}$

VOLUME I

PREFACE

xiii

1

EXECUTIVE SUMMARY

$1-1$

1.1 Coastal Siting

$1-4$

1.2 Inland Siting

$1-11$

1.3 Siting Concepts

$1-15$

1. 4 Transmission Lines

$1-25$

1. 5 Siting Concepts Evaluation

$1-27$

1.6 Alternative Systems Evaluation $1-35$

1. 7 Conclusions

$1-36$

1.8 Recommendations

$1-37$

1.8.1 Sites and Planning

$1-37$

1.8.2 Siting Concepts

1.8.3 Dry Cooling Systems

$1-39$

$1-40$

1.8.4 Risk Assessments

$1-40$

\section{VOLUME II}

2

INTRODUCTION

$2-1$

2. 1 Siting Factors 2-2

2. 2 Study Scope 2-5

3

COASTAL SITING 3-1

3.1 Environmental Characteristics 3-1

3.1.1 Physiography 3-1

3.1.2 Land Use 3-5

3.1.3 Geology 3-6

3.1.4 Seismology 3-9

3.1.5 Oceanography and Meteorology 3-12

3.1.6 Biology 3-15 
3. 2 Summary of Siting Considerations

3.2.1 Seismic Activity

$3-18$

3.2.2 Land Use

$3-20$

3.2.3 Biota

$3-20$

3.2. 4 Aesthetics

$3-22$

3.2. 5 Cooling Sources

$3-22$

3.2.6 Transmission Systems

$3-23$

3.3 Summary of Regional Characteristics

3.3.1 Topography 3-24

3.3.2 Faults and Areas of Seismic Activity 3-24

3.3.3 Geology

3.3.4 Unstable Landforms

$3-24$

3.3.5 Land Use

$3-26$

3.3.6 Key Species

3. 4 Candidate Sites

4.1 Environmental Characteristics 4-1

4.1.1 Physiography and Geology 4-1

4.1.2 Seismology 4-5

4.1.3 Hydrology and Water Resources 4-6

4.1.4 Meteorology 4-7

4.1.5 Biology 4-9

4.1.6 Population and Land Use 4-10

4. 2 Candidate Regions 4-12

5. 1 Once-Through Cooling 5-4

5.2 Transmission Lines 5-6

5. 3 Aboveground Concepts 5-13

5.3.1 Coastal 5-13

5.3.2 Inland 5-17

5.3.3 Hillside 5-21

5. 3.4 Low Profile 5-23 
TABLE OF CONTENTS (continued)

Section

Page

5. 4 Underground Concepts 5-26

5.4.1 Massive Igneous Rock 5-27

5.4.2 Massive Sedimentary Rock 5-37

5.4.3 Unconsolidated Materials, Beach 5-38

5.4.4 Nonmassive and Poorly Cemented Materials

$5-41$

5.4.5 Massive Rock, Faulted

$5-44$

5. 5 Offishore Concepts 5-48

5.5.1 Floating - Shallow 5-49

5.5.2 Floating - Deep 5-54

5. 5.3 Seabed 5-59

5. 5.4 Undersea $5-64$

5.5.5 Artificial Island 5-68

5.5.6 Natural Island 5-71

5.5.7 Tuned Sphere 5-75

5.6 Aboveground Floating - Lagoon 5-79

5.6.1 Facility Description 5-81

5.6.2 Considerations 5-81

6 ALTERNATIVE POWER SYSTEMS 6-1

6.1 Heat Rejection 6-2

6.2 Systems Development 6-4

6.3 Systems Description 6-6

6.3.1 Production Systems 6.6

6.3.2 Engineered Safety Features 6-8

6.3.3 Auxiliary Systems 6-10

6.3.4 Radioactive Waste 6-12

6.3.5 Radiation Protection 6-13

6.3.6 Site and Security 6-14

7 CONCEPTS EVALUATION 7-1

7.1 Evaluation Factors 7-2 


\section{TABLE OF CONTENTS (continued)}

Section

Page

7.2 Evaluations

$7-4$

7.2.1 Cost

7.2.2 Environment Impact

$7-4$

7.2.3 Feasibility

$7-10$

7.2. 4 Risk

$7-22$

$7-29$

7. 3 Acceptability

$7-44$

7.3.1 Cost Evaluation

7.3.2 Environmental Evaluation

$7-65$

$7-65$

7.3.3 Feasibility Evaluation

$7-68$

7.3.4 Risk Evaluation

$7-68$

7.3.5 Visual Image Evaluation

$7-71$

7.3.6 Potential Sites Evaluation

$7-71$

7. 4 Alternative Systems

$7-74$

7.4.1 Power Systems

$7-74$

7.4.2 Inland Plant Cooling Systems

$7-74$

7.4.3 Inland/LWR (Dry Cooling Tower)

7.4.4 Inland/Fossil Fuel, (Dry Cooling

$7-76$ Tower)

$7-80$

7.4.5 Inland/HTGR(GT), (Dry Cooling Tower)

CONCLUSIONS AND RECOMMENDATIONS

8.1 Conclusions

8.1.1 Sites

8.1.2 Transmissions

$8-2$

8.1.3 Siting Concepts

$8-3$

8.1 .4

Alternative Systems

$8-4$

8.1. 5

Summary

$8-5$

8.2 Recommendations

$8-6$

8.2.1 Sites and Planning

$8-7$

8.2. 2

Siting Concepts

$8-8$

8.2 .3

Dry Cooling Systems

$8-9$

8.2 .4

Risk Assessments

8-9 
TABLE OF CONTENTS (continued)

Appendixes

Page

VOLUME III
A
BIBLIOGRAPHY
$A-1$
B
ALTERNATIVE REACTOR SYSTEMS
B -1
C
EVALUATION METHODOLOGY
C -1
D
EVALUATION DATA
D-1 


\section{LIST OF TABLES AND ILLUSTRATIONS}

$\underline{\text { Table }}$

Page

1-1 Concept Total Acceptability Values 1-29

1-2 Bus Bar Costs 1-31

1-3 Miles of Potential Sites

3-1 Modified Mercalli Intensity (Damage)

$1-34$

Scale of 1931

$3-10$

3-2 Maximum Tsunami Rise or Fall Height at

Selected Stations for Recent Large Earthquakes 3-14

$3-3$

Coastal Parks

$3-27$

$3-4$

Education and Research Sites

$3-30$

$3-5$

Key Species

$3-31$

$4-1$

$4-2$

Key Species

4- 11

Areas of Restricted Land Use

4- 13

$4-3$

Summary of Environmental Characteristics

$4-14$

$6-1$

Unit Costs of Heat Rejection Systems

(Steam-Electric Plants)

$6-3$

$7-1$

Evaluation Factors Legend

$7-62$

Concept Total Acceptability Values

$7-64$

D-1

Summary Cost Estimate, Aboveground - Coastal

D-3

$D-2$

Summary Cost Estimate, Aboveground - Inland

$\mathrm{D}-4$

D-3

Summary Cost Estimate, Aboveground - Hillside

D-5

$D-4$

Summary Cost Estimate, Aboveground - Low Profile

D-6

D-5 Summary Cost Estimate, Aboveground -

Floating Lagoon

D-7

D-6

Summary Cost Estimate, Underground Massive Igneous

D-8

D-7 Summary Cost Estimate, Underground Massive Sedimentary

D-9

D-8 Summary Cost Estimate, Underground Unconsolidated Soils

$\mathrm{D}-10$

D-9 Summary Cost Estimate, Underground Nonmassive or PCM

D-11

D-10 Summary Cost Estimate, Underground Massive Rock Fault

D-12

D-11 Summary Cost Estimate, Offshore - Floating, Shallow Water

D-13

D-12 Summary Cost Estimate, Offshore - Floating Deepwater

D- 14

D-13 Summary Cost Estimate, Offshore - Seabed

D- 15

D- 14

Summary Cost Estimate, Offshore - Undersea

D-16

D-15

Summary Cost Estimate, Offshore -

Artificial Island

D-17 
LIST OF TABLES AND ILLUSTRATIONS (continued)

Table

$\underline{\text { Page }}$

D-16 Summary Cost Estimate, Offshore Natural Island

D- 18

D- 17

D- 18

Summary Cost Estimate, Offshore-Tuned Sphere

D- 19

Construction Schedule, Aboveground-Hillside,

Aboveground-Coastal, Offshore-Natural Island,

Aboveground-Low Profile

D-20

D-19 Construction Schedule, Aboveground - Inland

$\mathrm{D}-21$

D-20

Construction Schedule, Offshore - Artificial Island

D-22

$\mathrm{D}-21$

Construction Schedule, Offshore - Tuned Sphere

D-23

D-22

Construction Schedule, Underground -

Unconsolidated Soils

D-24

D-23 Construction Schedule, Aboveground-Floating

Lagoon; Offshore-Floating, Shallow Water;

Offshore-Floating, Deepwater; Offshore-Seabed

D-25

D-24 Construction Schedule, Offshore-Undersea,

Underground Massive Faulted, Underground-

Igneous, Underground-Sedimentary, UndergroundNonmassive or PCM

$D-26$

D-25 Cost Analysis Results and Ranking - Fixed Rate Charge, 12 Pct.

D-27

D-26 Cost Analysis Results and Ranking - Fixed Rate

Charge, 15 Pct.

$\mathrm{D}-28$

D-27 Cost Analysis Results and Ranking - Fixed Rate

Charge, 18 Pct.

$\mathrm{D}-29$

D-28 Concept Evaluation Summary Factor: Cost,

Weight 0.287

$\mathrm{D}-30$

D-29 Concept Evaluation Summary Factor: Environmental Impact Subfactor: Land Use, Weight 0.050

$D-31$

D-30 Concept Evaluation Summary Factor: Environmental Impact Subfactor: Land Restoration, W eight 0.033

$\mathrm{D}-32$

D-31 Concept Evaluation Summary Factor: Environmental Impact Subfactor: Visual Image, Weight 0.055

D-33

D-32 Concept Evaluation Summary Factor: Environmental Impact Subfactor: Physical Effects, Weight 0.075

D-34

D-33 Concept Evaluation Summary Factor: Environmental Impact Subfactor: Construction Impact, Weight 0.015

D-35

D-34 Concept Evaluation Summary Factor: Environmental Impact Subfactor: Multiple Uses - Heat and Plant,

Weight 0.033

D-36 
LIST OF TABLES AND ILLUSTRATIONS (continued)

$\underline{\text { Table }}$

$\underline{\text { Page }}$

D-35 Concept Evaluation Summary Factor: Environmental Impact Subfactor: Multiple Uses - Site,

Weight 0.040

D-37

D-36 Concept Evaluation Summary Factor:

Feasibility Subfactor: Technology, Weight $0.119 \quad$ D-38

D-37 Concept Evaluation Summary Factor:

Feasibility Subfactor: Potential Sites,

Weight 0.153

D-39

D-38 Concept Evaluation Summary Factor:

Risk, Weight 0.140

$\mathrm{D}-40$

$\underline{\text { Figures }}$

1-1 Aboveground - Coastal 1-16

1-2 Aboveground - Inland 1-18

1-3 Aboveground - Hillside 1-19

1-4 Aboveground - Floating Lagoon 1-20

1-5 Underground - Massive Igneous Rock 1-22

1-6 Offshore Floating Shallow 1-23

1-7 Cost Evaluation $1-33$

2-1 Main Transmission Networks 2-4

5-1 An Underground Gas-Insulated System for

An East-Coast Utility $\quad 5-8$

5-2 Two Gas-Insulated Circuits Aboveground
in The Substation of A Midwest Utility

5-3 Proposed Resistive Cryogenic Cable 5-11

5-4 Aboveground - Coastal 5-14

5-5 Aboveground - Inland 5-18

5-6 Aboveground - Hillside 5-22

5-7 Aboveground - Low Profile 5-24

5-8 San Onofre Power Plant 5-25

5-9 Underground - Massive Igneous Rock 5-30

5-10 Underground - Unconsolidated Materials, Beach 5-39

5-11 Underground - Nonmassive Poorly Cemented Materials

5-12 Offshore - Floating Shallow 5-50

5-13 Semisubmersible Platform 5-56

5-14 Offshore - Floating Deep 5-57

5-15 Offshore - Seabed 5-61

5-16 Offshore - Undersea 5-65 
LIST OF TABLES AND ILLUSTRATIONS (continued)

Figures

Page

5-17 Offshore - Artificial Island 5-69

5-18 Artificial Island Offshore at Long Beach 5-72

5-19 Artificial Island Offshore at Long Beach 5-73

$\begin{array}{ll}\text { 5-20 Offshore - Tuned Sphere } & 5-77\end{array}$

5-21 Aboveground - Floating Lagoon 5-80

7-1 Acceptability Aboveground Coastal 7-45

7-2 Acceptability Aboveground - Inland 7-46

7-3 Acceptability Aboveground - Hillside 7-47

7-4 Acceptability Aboveground - Low Profile 7-48

7-5 Acceptability Aboveground - Floating Lagoon 7-49

7-6 Acceptability Underground - Massive Igneous Rock 7-50

7-7 Acceptability Underground - Massive

Sedimentary Rock

7-8 Acceptability Underground - Unconsolidated Materials, Beach

$7-51$

$7-52$

7-9 Acceptability Underground - Nonmassive, Poorly Cemented Materials

$7-53$

7-10 Acceptability Underground - Massive

Rock Faulted

$7-54$

$\begin{array}{lll}7-11 & \text { Acceptability Offshore - Floating Shallow } & 7-55 \\ 7-12 & \text { Acceptability Offshore - Floating Deep } & 7-56\end{array}$

7-13 Acceptability Offshore - Seabed 7-57

7-14 Acceptability Offshore - Undersea 7-58

7-15 Acceptability Offshore - Artificial Island 7-59

7-16 Acceptability Offshore - Natural Island 7-60

7-17 Acceptability Offshore - Tuned Sphere 7-61

7-18 Cost Evaluation 7-66

7-19 Environmental Impact Evaluation 7-67

7-20 Feasibility Evaluation 7-69

7-21 Risk Evaluation 7-70

7-22 Concept Acceptability (Less Visual Image)

7-23 Potential Sites Evaluation 7-73

7-24 Acceptability Aboveground - Inland, LWR,

7-25 Acceptability Aboveground - Inland, Fossil

7-26 Acceptability Aboveground - Inland, HTGR(GT), 7-79

B-1 Reactor Vessel B-4

B-2 Steam Generator B-5 
LIST OF TABLES AND ILLUSTRATIONS (continued)

Figures

Page

$\begin{array}{lll}\text { B-3 } & \text { Reactor Coolant Circulating Pump } & \text { B-6 } \\ \text { B-4 } & \text { Pressurizer } & \text { B-7 } \\ \text { B-5 } & \text { Nuclear Steam Supply System } & \text { B-8 } \\ \text { B-6 } & \text { Prestressed Concrete Containment PWR NSS } & \text { B-11 } \\ \text { B-7 } & \text { BWR Direct Cycle Reactor System } & \text { B-29 } \\ \text { B-8 } & \text { BWR-PWR Containment Comparison } & \text { B-30 } \\ \text { B-9 } & \text { HTGR Prestressed Concrete Reactor Vessel } & \text { B-33 } \\ \text { B-10 } & \text { HTGR Steam and Water Systems } & \text { B-35 } \\ \text { B-11 } & \text { Flow Diagram, HTGR Helium Gas Turbine } \\ & \text { Cycle With Dry Air Cooling } & \text { B-46 } \\ \text { B-12 } & \text { LMFBR Building Containment "Loop" } \\ & \text { Primary System } & \text { B-52 } \\ \text { C-1 } & \text { Matrix A: Values Assigned } & \text { C-2 } \\ \text { C-2 } & \text { Matrix B: Weights Assigned } & \text { C-3 } \\ \text { C-3 } & \text { Concept Evaluation Worksheet } & \text { C-5 } \\ \text { C-4 } & \text { Acceptability by Evaluation Factor } & \text { C-7 } \\ \text { C-5 } & \text { Evaluation Factor Analysis } & \text { C-8 }\end{array}$

\section{Plates}

$\begin{array}{llr}\text { 1-1 } & \text { Coastal Site Summary } & 1-41 \\ 1-2 & \text { Inland Site Summary } & 1-42 \\ 1-3 & \text { Inland Water Resources } & 1-43 \\ 3-1 & \text { Physiography } & 3-34 \\ 3-2 & \text { Land Use } & 3-35 \\ 3-3 & \text { Geology and Seismology } & 3-36 \\ 3-4 & \text { Isoseismal Map of California (1769-1972) } & 3-37 \\ 3-5 & \text { Earthquake Intensity } & 3-38 \\ 3-6 & \text { Oceanography and Meteorology } & 3-39 \\ 3-7 & \text { Rare or Endangered and Some Key } & 3-40 \\ & \text { Biological Species } & 3-41 \\ 3-8 & \text { Coastal Site Summary } & 4-17 \\ 4-1 & \text { Inland Site Summary } & 4-18 \\ 4-2 & \text { Inland Water Resources } & 5-82 \\ 5-1 & \text { Aboveground - Coastal Site Plan } & 5-83 \\ 5-2 & \text { Aboveground - Coastal Plan at Turbine Deck Level } & 5-84 \\ 5-3 & \text { Aboveground - Coastal Plan at Condenser Level } \\ 5-4 & \text { Aboveground - Coastal Plan at Condenser } & 5-85 \\ & \text { Box Level } & 5-86\end{array}$


LIST OF TABLES AND ILLUSTRATIONS (continued)

Plates

Page

5-6 Aboveground - Coastal Section Through Facilities

$5-87$

5-7 Aboveground - Inland Site Plan

$5-88$

5-8 Aboveground - Inland Plan at Turbine Deck Level

$5-89$

$5-9$

Aboveground - Inland Plan at Condenser Level

$5-90$

5-10 Aboveground - Inland Section Through Facilities

$5-91$

5-11 Aboveground - Inland Section Through Facilities

$5-92$

5-12 Underground - Massive Igneous Rock Plan at Turbine Deck Level

5-13 Underground - Massive Igneous Rock Plan at Condenser Level

5-14 Underground - Massive Igneous Rock Section Through Reactor and Turbine Buildings

$5-93$

$5-94$

$5-95$

5-15 Underground - Unconsolidated Materials, Beach Plan at Turbine Deck Level

$5-96$

5-16 Underground - Unconsolidated Materials, Beach Section Through Facilities

5-17 Underground - Massive Rock Faulted Plan at Turbine Deck Level

5-18 Underground - Massive Rock Faulted Plan at Condenser Level

$5-98$

$5-99$

5-19 Underground - Massive Rock Faulted Section Through Facilities

$5-100$

5-20 Underground - Massive Rock Faulted Section Through Facilities

$5-101$

$5-102$

5-21 Offshore - Floating Shallow Composite Level Plan

5-22 Offshore - Floating Shallow Section

Through Facilities

$5-103$

5-23 Offshore - Floating Shallow Section

Through Facilities

$5-104$

5-24 Offshore - Artificial Island Plan at Turbine Deck

$5-105$

$5-25$

Offshore - Artificial Island Section

Through Facilities

$5-106$

$\mathrm{B}-1$

Pressurized Water Reactor Flow Sheet

B -57

B -2

HTGR Facilities

B- 58

B -3

HTGR Facilities

B- 59

B -4

HTGR Facilities

B -60

B- 5

HTGR(GT) Facilities

B-61

B- 6

LMFBR Facilities

B -62

B-7

LMFBR Production Flow

B -63 


\section{PREFACE}

This report contains the results of a study of power plant siting concepts. The work was performed under contract to Holmes \& Narver, Inc., by the Resources Agency, State of California, and the U. S. Atomic Energy Commission. Project coordination for the Resources Agency was provided by Mr. P. L. Clifton and Dr. D. B. Brice, and for the U. S. Atomic Energy Commission, Mr. J. O. Roberts.

A prime subcontractor to Holmes \& Narver (H\&N) in this project was Dames \& Moore (D\&M). The work involved principally the following personnel.

B. J. Garrick, $H \& N$

H. F. Perla, H\&N

J. M. Durican, H\&N

F. D. Ducey, $H \& N$

S. Kaplan, $\mathrm{H} \& \mathrm{~N}$

O. C. Baldonado, $H \& N$

J. R. Keaton, D\&M

D. E. Nels on, D\&M

\section{Project Director}

Project Manager and

Principal Investigator

Many other individuals and organizations provided specific information related to this study. Some of these are:

Aerospace Corporation, M. B. Watson

Babcock \& Wilcox, R. W. Dickinson

Environmental Quality Laboratory, California Institute of Technology, M. Goldsmith

General Electric Company, Nuclear Energy Division,

J. M. Smith and P. M. Murphy

Gulf General Atomic, A. J. Goodjohn

Department of Water and Power, E. Koffman

Offshore Power Systems, A Westinghouse-Tenneco Enterprise,

R. C. Nichols

Pacific Gas \& Electric Company, E. E. Hall

Sacramento Municipal Utility District, R. L. Wilson and

K. J. Mellor

San Diego Gas \& Electric, J. F. Dietz

Scripps Institute of Uceanography, University of California,

San Diego, J. D. Isaacs 
Southern California Edison Company, D. J. Fogarty, B. R. Laverty, O. J. Ortega, and F. A. McCrackin University of California, Los Angeles, R. C. Erdmann 


\section{EXECUTIVE SUMMARY}

Electric power consumption in California has consistently increased in greater proportion than the increase in population growth. The trend has been so great that some projections indicate the demand will double every 8 to 9 years. Generation of electricity by large central station nuclear power plants appears to offer significant advantages based on efficient utilization of natural resources, fuel availability, cost, and other factors when compared to alternative power plants currently within the state of the art. Of additional concern in planning for increased power demand and the need for new power plants is the fact that approximately 10 years are required to establish nuclear power facilities from the time sites are selected and environmental studies are begun. Therefore, it is necessary to begin site acquisition, design, and procurement actions today for plants which must be on line in the early $1980^{\prime} \mathrm{s}$.

The siting of power plants continues to be a central issue in providing an adequate, safe, and environmentally compatible supply of electrical energy. Principal issues in the siting of nuclear power plants have grown from containment and isolation in the 1950's, engineered safety systems and seismic resistance in the $1960^{\prime} \mathrm{s}$, and thermal effects and emergency core cooling in the early 1970's. Since the Calvert Cliffs decision, environmental impact has highlighted the siting issue.

It is necessary to consider alternatives to past and present approaches to the selection of sites for power plants and, in particular, to consider alternative plant concepts which might result in greater flexibility for selecting sites. This study was conducted to assist the State of California in the development of long range plans for siting of electric power generating plants in coastal zones and inland locations. The subjects covered in the study are very diverse and each capable of being investigated in great depth. It has been the intent in this study to avoid optimization and in-depth investigation on individual facets. It was deemed of greater value to identify, at this time, candidate concepts based on coastal or inland characteristics and to evaluate the se concepts on a relative basis, with regard to specific acceptability factors the reby placing them in perspective so that resources may be directed toward potentially preferred siting concepts.

In the course of pursuing the study, interviews were obtained with siting representatives of the larger California utility companies to obtain their siting philosophies and the results of their studies which are pertinent to this work. Discussions were also held with representatives of the nuclear steam supply system manufacturers who provided data relative to their products, studies they have performed relative to this 
work, and information on research and development being performed for advanced reactor systems and on siting concepts that may be applicable to the study. Further, the work performed by a number of other organizations was reviewed with them to obtain results of recent studies as might be related to this project. Finally, representatives of the Sierra Club were interviewed to obtain their views on siting and environmental impact, and discussions were held with representatives of the U. S. Atomic Energy Commission's Reactor Development and Technology and Licensing Divisions to obtain their views on the licensability of the alternative siting concepts which have been suggested.

Some of the factors which have greatly influenced siting decisions for nuclear and fossil fuel power plants are sources of large quantities of cooling water and close proximity to load centers. Additionally, nuclear plants require sites with particularly favorable geologic and seismologic characteristics at sufficient distances from populated areas so that safety of the public can be assured even in the event of highly improbable accidents. Environmental impact has rapidly become a prominent factor in selecting plant sites and probably will continue to be so in the future.

Among the environmental effects where proper planning is essential is the matter of reject heat from the plant. There are a number of ways in which reject heat can be dissipated; most of these rely on some form of evaporation. Ocean, river, or aqueduct water may be passed directly through the condensers and the heated water returned to the source where it is cooled through mixing and evaporation at the surface. Less used cooling systems include wet cooling towers (natural or mechanical draft), cooling ponds, and reservoirs. In these latter concepts, although similar quantities are passed through the condensers, the same water is recycled in the system and only about 2 percent of the total is replenished for evaporation losses and purging. The choice of system depends on water availability, economics which vary from site to site, and the environmental impact. It has been common practice to use the great abundance of ocean water for cooling purposes; and with care in siting and plant design, the ocean might continue to be an economical and acceptable cooling source. As land use has changed and the environment has become a major concern, there have been increased objections to continuing the location of power plants in many coastal areas just for the availability of natural waters and, therefore, alternative cooling systems and other locations a re being considered.

The demand for electrical power in California is concentrated in two major load areas, Los Angeles/San Diego and San Francisco/ 
Sacramento. According to data filed by the utility companies with the California Public Utilities Commission, * the power forecasts of annual peak loads in these two general areas and in other areas over the next 20 years are as follows:

Megawatts**;

\begin{tabular}{|c|c|c|}
\hline 1972 & 1981 & 1991 \\
\hline 15,319 & 29,667 & 56,060 \\
\hline 11,343 & 20,003 & 37,827 \\
\hline 495 & 930 & 1,600 \\
\hline$\overline{27,157}$ & $\overline{50,600}$ & 95,487 \\
\hline
\end{tabular}

The power will be supplied by means of many energy sources including hydroelectric, fossil fuel, geothermal, and nuclear. There are plants today using all of these sources; but is is clear that because of the environmental impact of fossil-fueled plants and projected domestic shortages of low cost fossil fuels, most next generation major power plants must utilize nuclear fuel to obtain thermal energy. This means that of the 23,500 megawatts ( $\mathrm{Mw}(\mathrm{e}))$ increase required by 1981 and an additional 44,800 $\mathrm{Mw}(\mathrm{e})$ required by 1991 , most of that demand will be met by large central station nuclear plants. Considering downtimes for refueling, maintenance, and repair, utility companies forecast that to meet the demands additional capacities of $28,300 \mathrm{Mw}(\mathrm{e})$ by 1981 and $51,700 \mathrm{Mw}(\mathrm{e})$ by 1991 will be necessary. The California Public Utility Commission estimates that without insurmountable licensing problems, nuclear power plants will provide over 19 percent of all power plant capacity in California by 1982 and might provide as much as 35 percent by 1992 .

Currently, nuclear power plants are being designed to use one or two 700 to $1,300 \mathrm{Mw}(\mathrm{e})$ units in an initial installation. Utility companies planning for longer range growth indicate that four to six $1,100 \mathrm{Mw}(\mathrm{e})$ units at one site could be reasonable, depending on plant proximity to population centers. With a capacity at each site averaging about 2,000 to $3,000 \mathrm{Mw}(\mathrm{e})$, perhaps 10 new sites are needed over the next 10 years and another 20 sites needed for the subsequent 10 years.

* General Order No. 131 Reports filed March 1, 1972.

** One megawatt equals one million watts. 
Power plants normally a re located reasonably near load centers so that transmission costs are minimized. Transmission lines also serve other functions in addition to carrying power to particular centers. They may increase reliability by tying with other power plants in the system to compensate for plant down periods, or they may join systems to obtain flexibility in meeting individual system demands. Transmission lines permit plant to be sited in remote locations; however, in practice to date, most nuclear plants have been located at least 5 to 10 miles from population centers of 25,000 or more. Although there is no AEC guide yet nor requirement for revising these distances, it is possible that greater experience or use of alternative plant siting concepts could reduce minimum acceptable distances.

A significant constraint placed on the selection of suitable nuclear power plant sites is the impact of anticipated seismic activity or ground motion. Locations a more desirable where seismic activity is a minimum or where aseismic design can be provided without exceedingly high cost penalties. Some alternatives to current siting concepts might offer less susceptibility to ground motion than others and thereby potentially increase the number of acceptable sites to include more seismically active areas than would otherwise be considered.

There are many other factors of importance when seeking an acceptable power plant site. First, the coastline of California is a particularly desirable location for many uses. These include parks and other recreational developments, residential development, conservation and preservation of scenic values, and refuges for wildlife or endangered species. Industry also relies on coastal resources, particularly oceandependent industries such as shipping and fishing. These industrial needs for which there is no suitable inland substitute must be considered in conjunction with the other coastal zone uses. The construction of contemporary nuclear power plants may have an impact on nearby areas more suitable for other uses. Second, after investigations at specific locations, it might be shown that sites are unsuitable for the contemporary power plants and that alternative plant siting concepts would result in more acceptable conditions. Perhaps with little cost penalty, a different power plant approach is available; one which would permit continued use of the coastal zone for many purposes, providing areas for power plant siting and using the ocean for cooling water; or an approach where sites away from the coastline might provide an equally acceptable, or perhaps better, solution.

\subsection{COASTAL SITING}

For purposes of this study, the coastal zone was defined as the area to about one-quarter mile inland and the distance seaward about 
three miles from the shore, but including the off shore islands which are at somewhat greater distances. However, in reviewing the potential siting of power plants, consideration was given to possible coastal locations as far as 1-1/2 miles in from the shore.

An evaluation of the pertinent aspects of the environment of the coastline of California must include consideration of physiography, land use, geology and seismology, oceanography and meteorology, and biology and ecology.

The terrain of the California coastline varies from flat marshland to nearly vertical cliffs. Harbors and bays are found all along the coast.

Three major mountain ranges are found along California's 1, 072 mile-long coast. The Coastal Ranges extend from the Oregon border south to the Santa Maria Valley; the Transverse Ranges extend easterly from the Coastal Ranges to the Los Angeles basin; and south of the Los Angeles basin to the Mexican border, the Peninsular Ranges are found.

Portions of frontal areas contain sandy beaches and low lying terraces. In some areas, the coastline is rugged, sloping to elevations over several thousand feet. Large coastal plains are found and the se often are areas of heavy population. Offshore in southern California, there are a number of islands having shorelines with pocket beaches, low terraces, or 50 to 200 -foot cliffs.

The continental shelf is the gently sloping submerged marginal zone of the continents extending from the shore to an abrupt increase in slope (continental slope). In northern California, the shelf varies from 2 to 30 miles in width, averaging about 15 miles. South of Point Conception, the shelf narrows, averaging about 4 miles in width. There are only a limited number of shallow water areas which are 3 miles from shore. These few miles of about 40 to 60 -foot depths of water occur principally offshore from San Francisco, Ventura, and La Jolla. In most coastal zones, the 40 to 60 -foot depths occur less than a mile from shore.

Land north of Santa Barbara generally is relatively undeveloped except in the vicinity of San Luis Obispo, Monterey, Santa Cruz, San Francisco, Eureka, and Crescent City. Except for a few locations in Ventura County and near Oceanside, the coastal zone south of Santa Barbara is developed and populated.

Archeologic and historic sites represent significant reminders of past cultures which affected the development of the State and about 60 
such sites dot the coastline of California. State and national parks and beaches, ranging from less than 1 to more than 30 coastline miles, are found all along the California shoreline. Most of these, however, are found in the central and southern counties. About 40 education and research sites are located on or are planned for specific areas along the coastline. These sites, ranging in extent from a few hundred feet to over 10 miles, present areas of value for marine-oriented research and educational activities.

Geology in most of the California coastal zone is mixed in varying degrees of fractured rock units which are sedimentary or volcanic in origin. Most of this material is quite shattered and friable. The area from Point Arena to San Francisco is typified by granitic basement complexes on the west side of the San Andreas fault and weaker magnesium and iron-rich basement complexes on the east associated with marine sedimentary rocks and some volcanics. Much of this is somewhat fractured. More granitics are found south of San Francisco near the Monterey area.

From Point Arguello to the Oxnard Plain, there is a great deal of massive durable sandstones interbedded with hard siliceous shales. The area south of that is typified by less durable sedimentary and volcanic rocks.

The general geology of the sea floor can be inferred by projecting some of the faults and rock types found on the mainland and offshore islands to sea. However, exact information offshore is limited to the Santa Barbara Channel and the Los Angeles basin where extensive oil exploration has occurred, and a few areas where specific exploration was performed.

The margin of the Pacific Ocean is a notoriously active seismic zone. The three modes of events that can result from seismic activity include destructive vibratory ground motion, ground failure, and seismic sea waves.

Vibratory ground motion can cause damage to structures by deformation due to shaking. A nearby earthquake will have a higher intensity at a particular site than a distant earthquake of the same magnitude. Therefore, the San Andreas fault zone, capable of generating an earthquake having a Richter scale magnitude of 8.5 is within destructive reach of a considerable portion of the coastline. Surface ruptures, or fault breaks, can be particularly destructive if a structure has been placed across an active fault that undergoes slippage. Mass movements (landslides, mudflows, and rockfalls) can 
be caused by earthquake activity. A saturated, loosely compacted granular material can lose its strength if earthquake shaking causes the load on the soil to be transferred from grain-to-grain contact to the pore water.

Seismic sea waves (tsunamis) usually generated by distant marine earthquakes, can also cause damage along coastal areas. Seiches (locally generated "sloshing") can cause damage in enclosed or partially enclosed areas.

Structures in seismically active areas must be designed according to established criteria and for a given level of risk. Since fault movements generate seismic activity, their location and size represent a key area of interest and in many cases represent zones to be avoided. The major fault zone in California is the San Andreas rift zone. However, many other faults are found near California's coastline. The offshore areas are faulted similarly to their adjacent onshore areas, but these faults are only approximately located and are not all known.

The nuclear power plant siting problem in California becomes quite different from corresponding problems experienced in most othe $r$ areas of this country, since it is most often necessary to first consider the seismic hazard. Considering the present state of the art in the design of nuclear plants to withstand both ground motion and displacement, there are vast areas of California which would have to be studied carefully to prove that plants can be licensed and safely operated. Other areas may have to be excluded entirely.

In the case of siting plants underground, additional faulting may be exposed in the cavities developed for various components of the facility. Each fault would have to be carefully examined and dated to determine if it is active in order to satisfy AEC regulations. Therefore, this process could make the licensing of an underground facility even more difficult to accomplish than for an aboveground facility at the very same site, and at considerably greater expense.

The coastal biology includes rare or endangered species as well as important communities of plant and animal life. As examples, there are found along California's coast, several animal species including the southern sea otter, southern bald eagle, the Guadalupe fur seal, the American peregrine falcon, and the California least tern. Not only are the rare and endangered species important, but there are numerous other species and communities of land and sea wildlife or plant life such as kelp and pygmy forests, and anadromous and ocean fisheries about which 
there is wide concern. It is necessary to show that a specific project will have little consequential effect on these living resources.

Another consideration encountered in site selection is one of aesthetics. This area is almost wholly subjective and holds opinions so wide ranging as to make a unanimous choice virtually impossible. If one considers the aboveground plants aesthetically unappealing, an underground plant may be a reasonable choice for a siting concept because it would minimize the controversy. At an inland site, where a large natural draft cooling tower might be considered, the intrusion on the natural scene is substantial. However, some people might view the current designs of a natural draft cooling tower as extremely interesting and appealing.

To derive regions which might contain suitable sites, Plate 1-1 summarizes key siting factors of topography, faults and areas of seismic activity, geology, unstable landforms, land use, and key biological species. Summarizing these:

1. Topographic features on land vary from low elevation beach areas to high cliff and mountainous terrain, the latter being prevalent.

2. The materials contained in these profiles vary from saturated or dry unconsolidated soils to massive rock moderately jointed.

3. The land is used for many purposes. However, over 60 percent of it is almost completely undeveloped and unpopulated. Some of it is heavily populated and used for residential, industrial, or commercial purposes; and, of course, much of the land is only nominally occupied.

4. There is a large number of animal species in the coastal area, some of them rare and endangered, sharing the coastal environment with humans.

5. The vegetation throughout the coastal zones is generally sparse and of low profile with forested areas predominantly limited to the northern part of the State.

6. The offshore zones are typified by a continental shelf which drops off rather rapidly from the shoreline. Obviously, there are shallow water depth contours offshore, but only a limited 
number of coastal miles have large shallow areas 3 miles from the shore and almost none exist at greater distances.

7. Most of the water out to about 3 miles (State jurisdictional limit) is at least 200 to 600 feet deep and, in general, is substantially in excess of that at 12 miles out (Federal jurisdictional limit).

8. There are several islands located offshore, and they increase the diversity in the nature of the California coast.

From the data contained in Plate $1-1$ regions a re identified which appear to conform with the regulations or constraints that might govern plant site acceptability for potential siting concepts. Those which have been investigated fall into three categories: aboveground, underground, and offshore. Site characteristics peculiar to these concept options were identified and became the basis for locating the candidate sites shown. Site physical criteria corresponding to siting concepts which are defined later are as follows:

1. Aboveground Sites

a. Beach or Low Terrace - Low elevation, close to shore, suitable for coastal concept.

b. Hilly or Rugged - Relief exceeding 200 to 300 feet, within 1 to $1-1 / 2$ miles of shore, suitable for hillside and low profile concepts.

c. Lagoon or Beach - Low elevation, adjacent to shore, containing lagoon or capable of being dredged, suitable for floating plant concept.

2. Underground Sites

a. Massive Igneous Rock, Hilly - Relief exceeding 300 feet, within 1 to $1-1 / 2$ miles from shore.

b. Massive Sedimentary Rock, Hilly - Relief exceeding 300 feet, within 1 to $1-1 / 2$ miles from shore.

c. Unconsolidated Materials, Beach - Low elevation, near shore. 
d. Nonmassive or Poorly Cemented, Hilly - No constraint on relief dimensions, within 1 to $1-1 / 2$ miles from shore.

e. Massive Rock, Faulted Zone - Relief exceeding 300 feet, within 1 to $1-1 / 2$ miles from shore, massive igneous or sedimentary rock, in faulted zones.

3. Offshore Sites

a. Shallow Water (40 to 60 feet) at 3 Miles - Suitable for floating plants in shallow water and artificial island concepts.

b. Shallow Water (40 to 60 feet) Close-In - Less than 3 miles from shore, suitable for floating plants in shallow water and artificial island concepts.

c. Moderately Shallow Water (250 to 300 feet) at 3 Miles Suitable for plant located on the seabed.

In each case, after the basic site features and the potential zones were identified, portions of these zones were eliminated if they contained coastal faults or were in areas of destructive ground motion. Also, portions in close proximity to population centers were identified by not showing them as solid bars. Population centers were determined by identifying cities or areas having populations in excess of 25,000 . Since plants licensed today are no closer to population centers than about 5 miles, this distance was used in the study as the minimum to be excluded in siting considerations.

Plate 1-1 provides an initial identification of regions which includes potentially acceptable sites. Regions which are indicated as being hilly contain occasional low terraces or beaches which are too small to identify on the Summary Sheet. Detail maps would reveal these pocket sites which might be suitable in size for a plant location. Diablo Canyon south of Morro Bay and the proposed site north of Davenport are examples of this situation.

Plate $1-1$ is a tool for initial searches for suitable areas. However, it is emphasized that each of the candidate regions requires detailed site investigations to validate its suitability for the concepts later discussed. This includes a geologic exploration and seismologic survey as well as a detailed assessment of the other environmental factors, many of which are summarized on Plate 1-1 under Land Use and Key Species. It also should be noted that detailed investigations 
of the same depth in some of the areas not identified as candidate areas might produce some suitable sites.

\subsection{INLAND SITING}

Land use conflicts exhibited in the coastal zone may be significantly less in portions of the interior of the State, especially since the interior offers a greater area from which to seek suitable plant sites. Other significantly important factors relate to a search for less seismically active areas, sites removed from population centers and less costly project locations. Further, considering ecological and related factors, the search becomes one for sites where the construction and operation of a generating station might involve smaller environmental impact.

The inland region has great topographic and geologic diversity. Included within its limits are an as semblage of physiographic features that reflect a complex geologic history and a wide variety of rock types and structural elements ranging from mountains and plateaus to valleys and deserts.

Of the eleven provinces shown on Plate 1-2, most can be eliminated from consideration due to their topography of high relief and ruggedness. A few valleys of moderate size in the Modoc Plateau, Coast Range, and Transverse Range Provinces are suitable from the standpoint of topography, but most of these have close proximity to urban centers or prohibitive land use and are of little interest. Notable exceptions are the Salinas Valley and the Cuyama Valley in the southern Coast Ranges, both relatively near the San Andreas Fault Zone, the Scott Valley in the Cascade Range, and several valleys in the Modoc Plateau. The Salinas and Cuyama Valleys are well located with respect to load centers, but seismicity and land use alternatives may rule them out. While far from urban centers and in areas of abundant water supplies, the valleys of the Cascade Range and Modoc Plain lie in areas of recent faulting and volcanic activity. The Great Valley, Mojave Desert, Colorado Desert, and Basin-Range Provinces contain substantial areas of suitable topography.

The Great Valley, a nearly flat alluvial plain about 450 miles long and an average of 50 miles in width, comprises over one-tenth of the area of California. Elevations of the plain are generally less than a few hundred feet above sea level but increase to over one thousand feet near the margins of the province. The present flat valley floor is composed of gravel, sand, silt, and clay sediments deposited 
primarily by streams and shallow lakes. The principal landforms in the valley are river floodplains, overflow lands and lake bottoms, low alluvial plains and fans, and dissected alluvial uplands. Major areal ground subsidence has occurred in three extensive areas between Sacramento and the south end of the valley, resulting from oxidation of peat lands; intensive pumping of confined aquifers; near-surface compaction of low density alluvial fan deposits; and, in some cases, from the removal of oil and gas.

The Mojave Desert region is a fault-bounded, triangular-shaped area characterized by mountain ranges of varied trends between which are enclosed valleys. The valleys lack external drainage and often contain playas. While areas adjacent to the Colorado River are only a few hundred feet in elevation, most of the desert basins lie between 1,000 and 3,000 feet elevation.

The Colorado Desert is an elongate, low-lying depression whose alluviated floor is separated from the Gulf of California by the Colorado River delta and is in part occupied by the Salton Sea. Elevations range from about 230 feet below sea level to over 300 feet above sea level. Much of the province is below sea level.

The Basin-Range Province is characterized by north-trending ranges, intervening valleys and basins, and interior drainage. Elevations in the Basin-Range Province vary widely, from 282 feet below sea level in Death Valley to over 14,000 feet in the mountains. Most basins lie between 3,000 and 7,000 feet elevation.

Many of the major known faults of California are shown on Plate 1-2. The most significant and famous fault zone in California is the San Andreas rift zone. Of the four provinces described above, the western Mojave Desert, the Colorado Desert, and the Basin-Range provinces contain a considerable number of known active faults. The Great Valley province and the eastern Mojave Desert appear to contain fewer active faults. Nearly all of the Colorado Desert and BasinRange provinces are in relatively close proximity to known recently active faulting. Since the presence of active faults imposes design criteria constraints and may preclude licensing, highly detailed geologic investigations will be necessary in areas of known faulting.

Interpretation of historic data and geologic information has yielded zones where maximum seismic intensities can be expected. Zones representing three levels of intensity are presented on Plate 1-2. Although suitable sites may be found in the higher Seismic 
Intensity Zone III regions, design criteria constraints may be greater and foundation conditions may have to be better than would be necessary in lower intensity zones.

The California water supply problem essentially is one of maldistribution of supply and use. The supply of water is greatest in northern areas of the State, whereas the demand is greatest in southern areas. This problem has brought about extensive water projects to redistribute and conserve water supplies. Plate 1-3 indicates the complex drainage and transport systems in the inland regions, and presents the hydrologic areas and major aquifers which together constitute the hydrologic regime of current water sources for inland sites.

When considering nuclear power plants, meteorological conditions generally will not impose major constraints upon siting. The low humidity and consequent high evaporation rates of the deserts and inland valleys will allow efficient operation of supplemental wet cooling facilities, but will thereby produce a high makeup water demand. Fogging of the atmosphere from increased humidity produced from cooling towers is unlikely in most of the desert areas. Northern areas may have greater incidence of this problem during certain periods of the year and therefore place greater demands on tower performance.

The diversity of California biota is as wide as that of the topography and climate. Vegetative communities prevalent in the areas of interest include mixed perennial native bunch grasses, southern oak woodland, bush scrub and chaparrel, and Pinyon-Juniper and Joshua tree woodlands. As these communities are widespread, the animals that occupy them are diverse and include deer, coyotes, chipmunks, rats, racoons, weasels, mountain lions, and a highly diverse bird fauna such as the California Condor and the Southern Bald Eagle.

Major cities in the Great Valley are Sacramento, Stockton, Fresno, Bakersfield, Modesto, and Lodi. Although other small cities and towns are located throughout the valley, much of the population is located in the central and southeast quarter of the valley. Most of the land in the Great Valley is used for agricultural and livestock production. Irrigation of large parts of the valley make possible extensive crops of fruits, cotton, hay, vegetables, and grains. Use of land for grazing is important in many parts of the valley which are not irrigated. The Mojave Desert and the Basin-Range are regions of low population and minor land use. Irrigation has allowed agricultural production of a small percentage of the land, grazing exists, 
and only a few small cities are located in these desert areas. As a result of extensive irrigation, a large part of the Colorado Desert is now used for agricultural production. Several small cities serve the agricultural community and are year-around resorts.

The inland siting concept reviewed in the study is an aboveground plant similar to those now being planned, built, and operated in the United States. On that basis, large areas of the State virtually can be eliminated if they do not contain some of the basic site requirements characteristic of licensed plants.

Earlier it was noted that of the eleven provinces in the State, seven can be eliminated from consideration due to their topography of high relief and ruggedness, their close proximity to urban centers, prohibitive land use, or predominance of seismically active areas within their bounds. The remaining provinces are the Great Valley, Mojave Desert, Colorado Desert, and Basin Range. Within these provinces four principal constraints can be identified for siting of conventional aboveground nuclear power plants. These are superimposed on Plate 1-2. Conventional designs are considered only for areas which are relatively flat and which offer no great topographic obstructions to design or construction. Mountainous or otherwise relatively inaccessible regions have been eliminated from consideration. These and the seven provinces which were eliminated are represented by the hatched areas. Next, centers of population greater than 25,000 are removed, recognizing that smaller population centers would still be avoided. Conflicting land use such as major parks, monuments, reservations, preserves, and refuges is also eliminated from consideration. Regions of high seismic intensity and major known active faults, or where the historic record indicates damage has occurred in the past, are also eliminated.

Areas of potential subsidence may be subjected to long periods of countermeasures after subsidence has been deleted. This was particularly true in the Wilmington oil field where it took years to halt the activity. Further, such countermeasures might not be in the best interests of the owners, and this potentially could cause the power plant to be shut down while awaiting legal resolution. Therefore, regions known to be subject to ground subsidence are eliminated and thereby the suitable area is further reduced.

Detailed site investigations may present exceptions to the eliminated regions, but the "white" areas remaining on Plate 1-2 after consideration of topography, population and land use, and seismicity suggest locations where suitable sites might most easily be found. It is recognized that many potentially suitable locations might be found to have more severe 
restrictions than those identified herein and that areas apparently less suitable might offer additional site development potential. Detailed site investigations would be needed for verification.

Water resource availability has been considered as shown on Plate 1-3 where it is seen that cooling water may not be available where required in the specific inland areas. It is seen that the Great Valley and Mojave Desert are closer to a larger number of water sources than other regions and could be given preference. Water might be provided to locations in a number of ways, including reassignment of existing water allocations, development of groundwater basins, collection of irrigation drainage, and additional water transport from areas of high precipitation.

\subsection{SITING CONCEPTS}

A number of alternatives to an aboveground coastal nuclear power plant were studied. As a group, the concepts often are peculiar to certain siting conditions in order to offer advantages. Collectively, these conditions constitute a wide variation in the physical features of sites. Fortunately, there is a great contrast in the physical features of the State, thus permitting most of these concepts to be considered for siting in California.

The siting concepts are grouped by their general location: aboveground, underground, or offshore. For this study, an 1,100 $\mathrm{Mw}(\mathrm{e})$ aboveground facility with a light water reactor ( $L W R$ ) system and location similar to the planned San Onofre Unit 2 south of San Clemente has been selected as the base line coastal concept. Consideration was given to the use of liquid metal fast breeder reactor and high temperature gas reactor systems in lieu of the light water reactors to determine their effect, if any, on siting concepts. Other alternatives were briefly reviewed and were applied to the inland concept because that appeared to be the one basic concept to which each of these alternatives might apply most effectively. These latter are an inland LWR plant with a dry cooling tower, an inland fossil fueled plant with a dry cooling tower, and a plant using a high temperature gas-cooled reactor with a gas turbine and dry cooling tower.

Features of the base line siting concept and sixteen alternative concepts using LWR steam supply systems and once-through or evaporative cooling are summarized as follows:

1. Aboveground-Coastal - The coastal concept shown in Figure $1-1$ is similar to the San Onofre Unit 2 planned to be built on the site developed for the existing San Onofre unit south of San Clemente. It would be at low elevations and may be situated on a coastal plain or beach, or on a low terrace adjacent to the ocean. With these characteristics, 


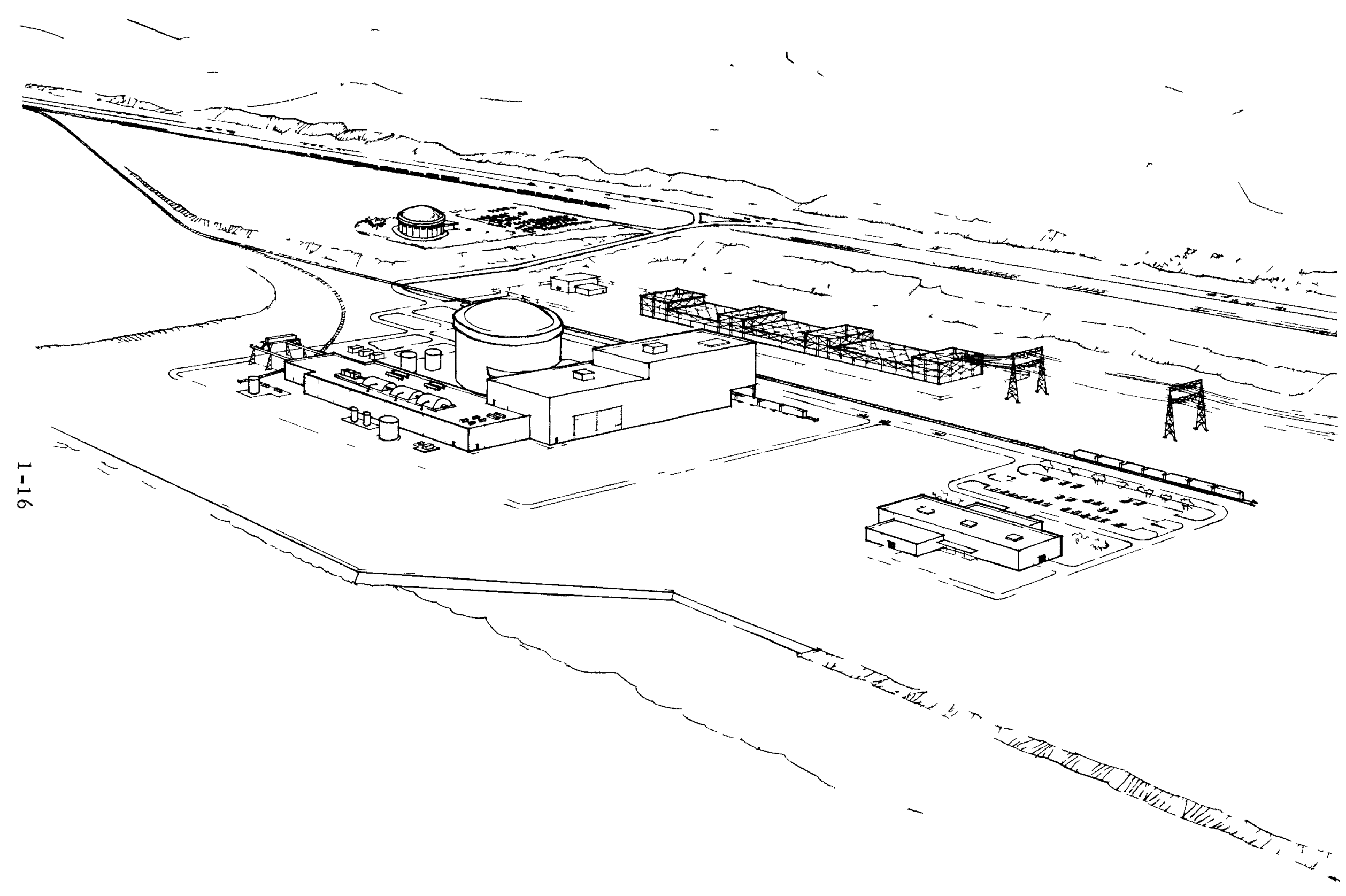

FIGURE 1-1

ABOVEGROUND - COASTAL 
condenser cooling water pumping facilities are minimized as are friction losses resulting from longer intake lines to the condensers.

2. Aboveground-Inland - The inland concept shown in Figure $1-2$ is included to suggest that an alternative to supplying powe $r$ in coastal zones could be in an inland location using transmission lines to the coastal area. The plant would be located on a plain and may be in a high or low desert environment. Water in large quantities will be necessary for an evaporative cooling system until such time as dry cooling towers are proven feasible in the sizes required. It is assumed that sufficient quantities of cooling water for use of evaporative cooling towers can be made available by reallocation or can be developed.

3. Aboveground-Hillside - Shown in Figure 1-3, this is similar to the coastal plant but is set in the Coastal Ranges so that it is not seen from the coastal road. It might be at an elevation of perhaps 150 feet and as far as $1-1 / 2$ miles in from the shore. It would be surrounded by hills having elevations at least 250 to 300 feet higher so that the plant is hidden from view at a coastal highway.

4. Aboveground-Low Profile - Similar to the coastal plant, this concept is placed in a cut so that when viewed from the coastal road only part of the plant is visible. The plant might be located on either side of the coastal road.

5. Aboveground-Floating Lagoon - A floating platform mounted nuclear plant similar to that offered by Offshore Power Systems would be placed in an existing or constructed lagoon at the shore as seen in Figure 1-4. The floating plant in a lagoon requires a site with very low elevation to minimize the excavation required to develop a sea level canal or inlet. The identification of sites was based on having sufficient distance from the shore to allow consideration of a marina development or construction of a coastal road on the shore side of the plant. The plant would provide some aseismic design advantage, avoid many of the hazards associated with offshore locations, and provide an opportunity for joint use of the lagoon with a marina or other water sports activity.

6. Underground-Massive Igneous Rock - With the exception of the pumping station and some vent structures, the entire plant, shown in 


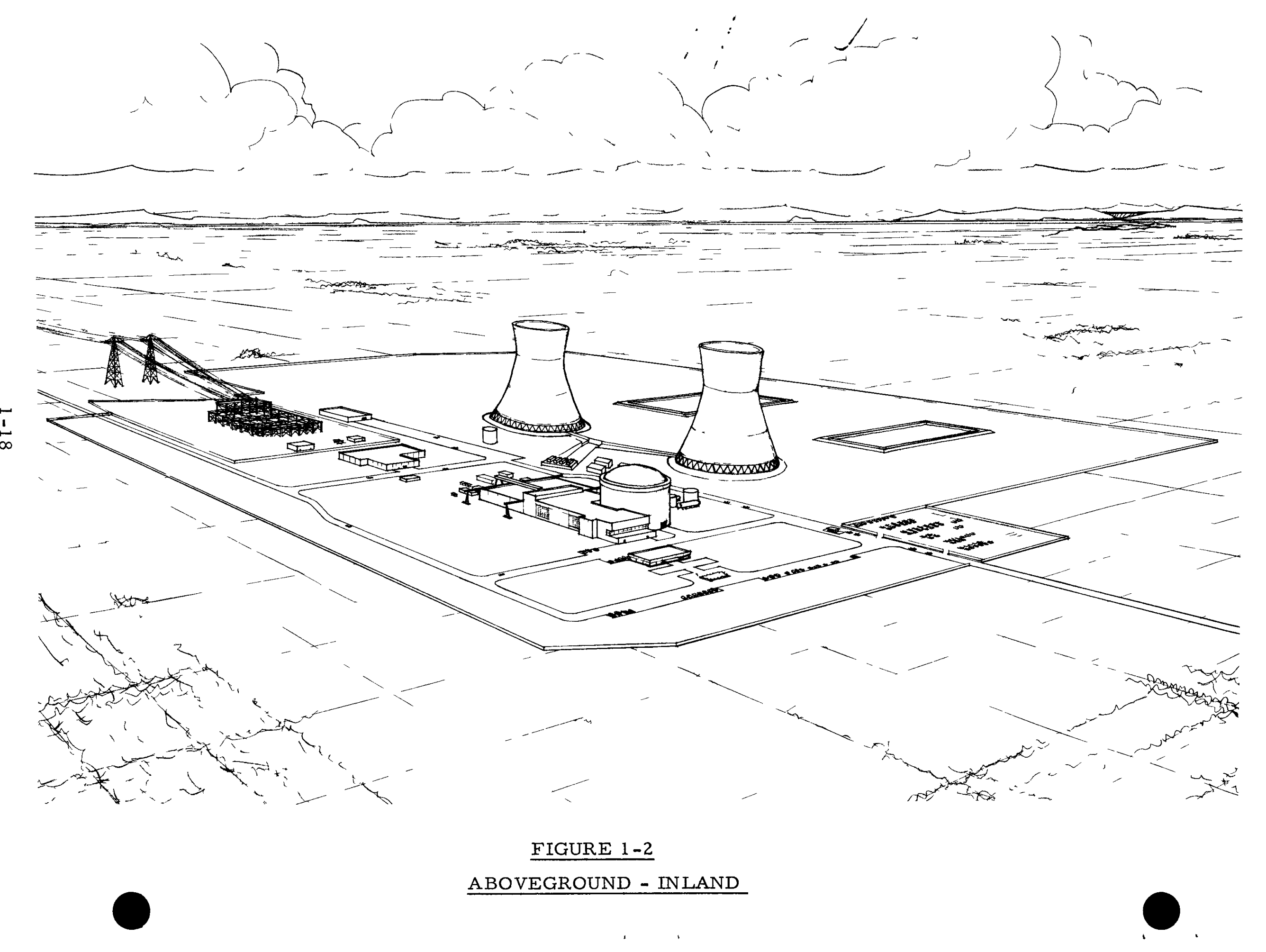




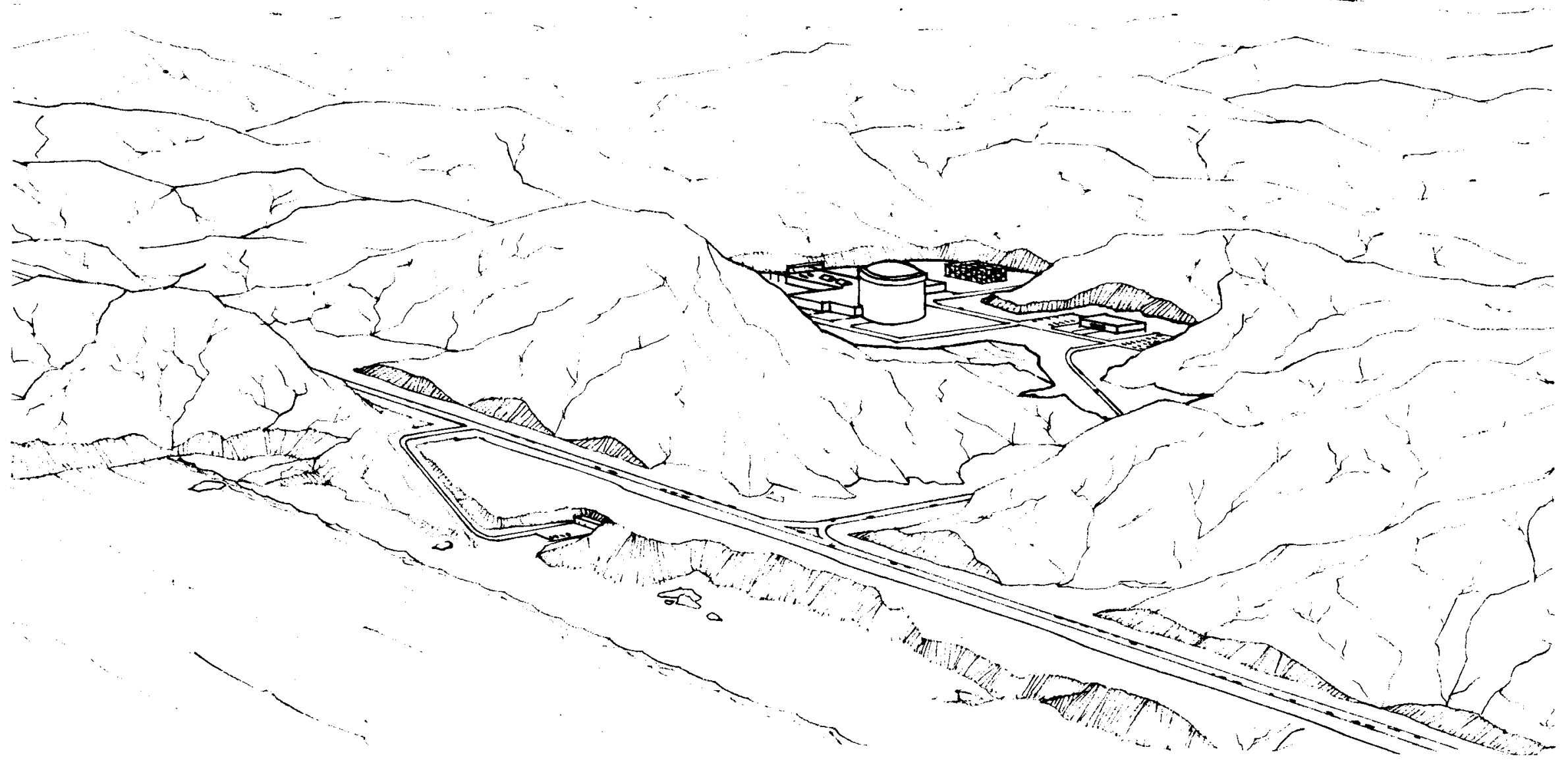

FIGURE $1-3$ 


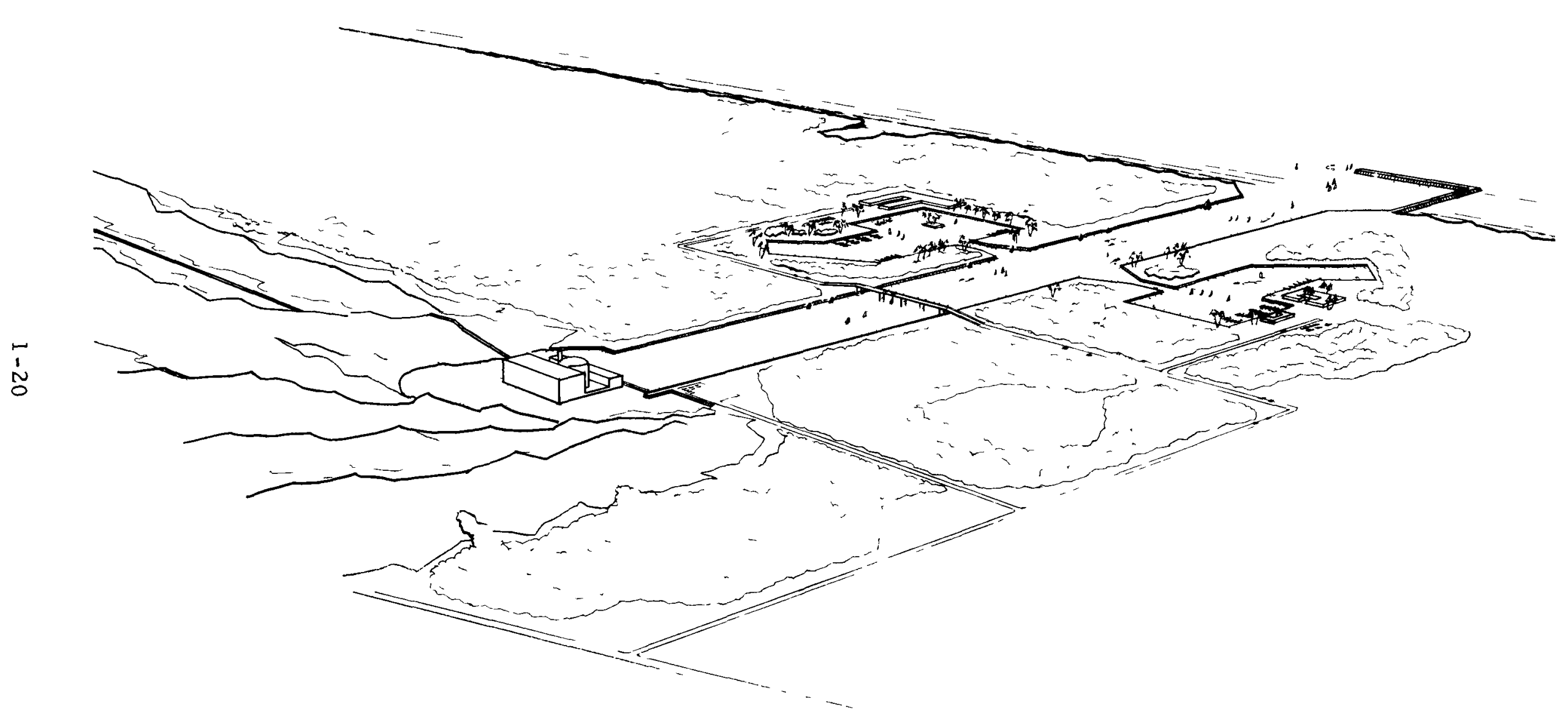

FIGURE 1-4

ABOVEGROUND - FLOATING LAGOON 
Figure 1-5, would be located in from the shore, underground in massive igneous rock, and in hilly terrain to permit tunnel access to the facilities from the coastal road. Sites would be at elevations of about 150 feet.

7. Underground-Mas sive Sedimentary Rock - This is similar in concept to the plant located in igneous rock but in a material of greater abundance in California than the igneous rock.

8. Underground-Unconsolidated Materials, Beach - The concept is an underground plant located at a beach site having poorly cemented materials and a high water table. Unique features include the use of circular, massive buildings to the maximum extent possible since that is a more efficient design for resisting lateral saturated soil pressures and uplift forces.

9. Underground-Nonmassive or Poorly Cemented Materials The plant would be located in a hillside area where surface cut-and-cover methods would be used to construct an underground facility. These locations might place the plant in from shore as much as 1-1/2 miles in some cases. Facilities would be similar to those in unconsolidated materials, but loading would be less severe.

10. Underground-Massive Rock, Faulted - An opportunity is provided for assessing an underground concept in rock if the locations contain faulting potentials no greater than a few inches. This would expand the number of sites that might be available.

11. Offshore-Floating Shallow - The Offshore Power Systems floating platform mounted plant shown in Figure 1-6 would be prefabricated and placed offshore in water depths of between 40 and 60 feet, using a breakwater for protection against waves and ship collision. As water depths increase, breakwater costs rise sharply, and 60 feet perhaps is an upper limit worthy of consideration. Sites in the range of 40 to 60 feet of water depth at 2-1/2 to 3 miles from the shore are limited to only 7 miles of the coastline. If constrained to greater distances from the shore, additional sites are virtually nonexistent. If not constrained by minimum offshore distance, sites are substantially increased if plants can be located about one mile from shore. 


\section{$\%$}

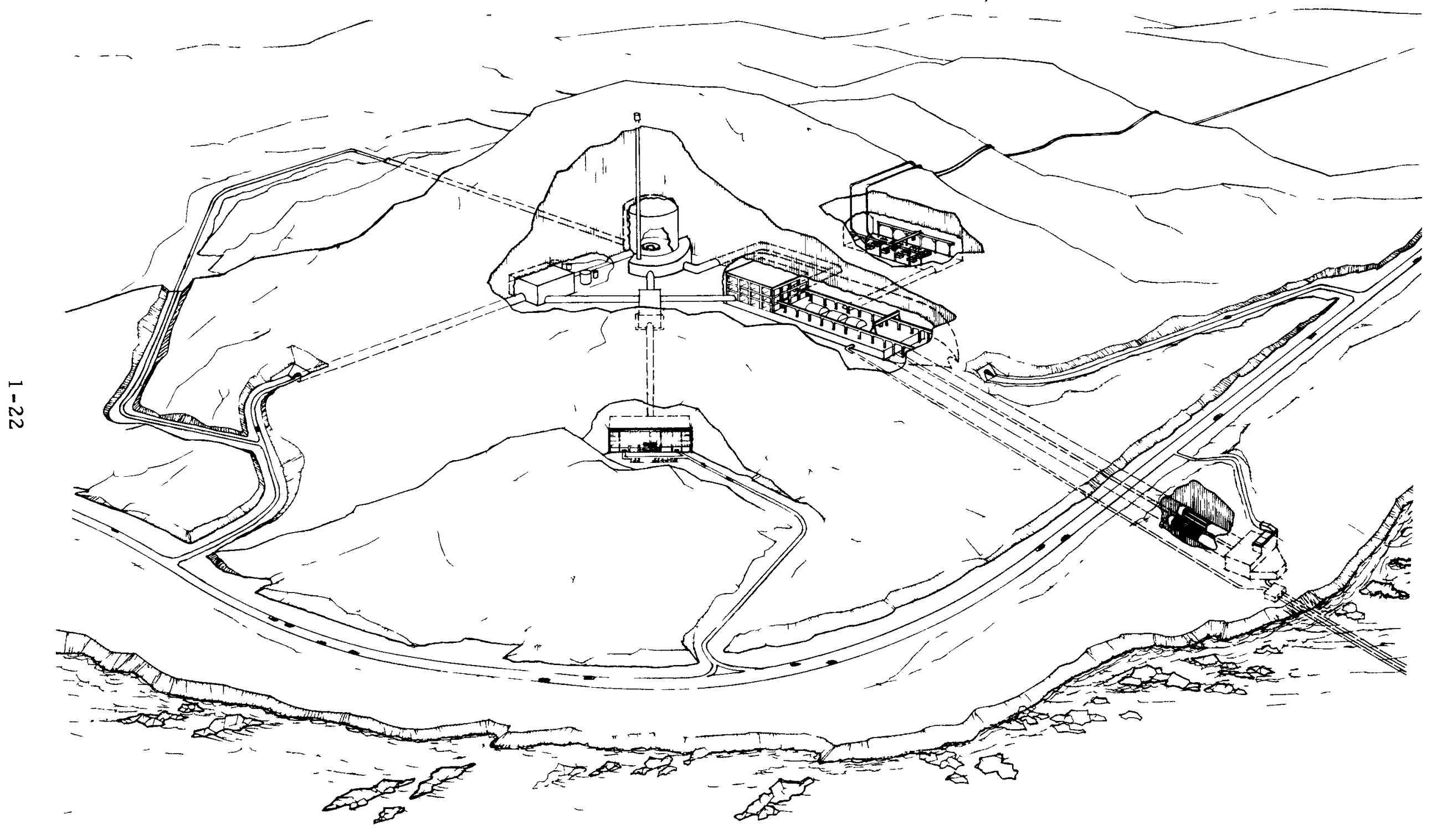

FIGURE 1-5

UNDERGROUND - MASSIVE IGNEOUS ROCK 


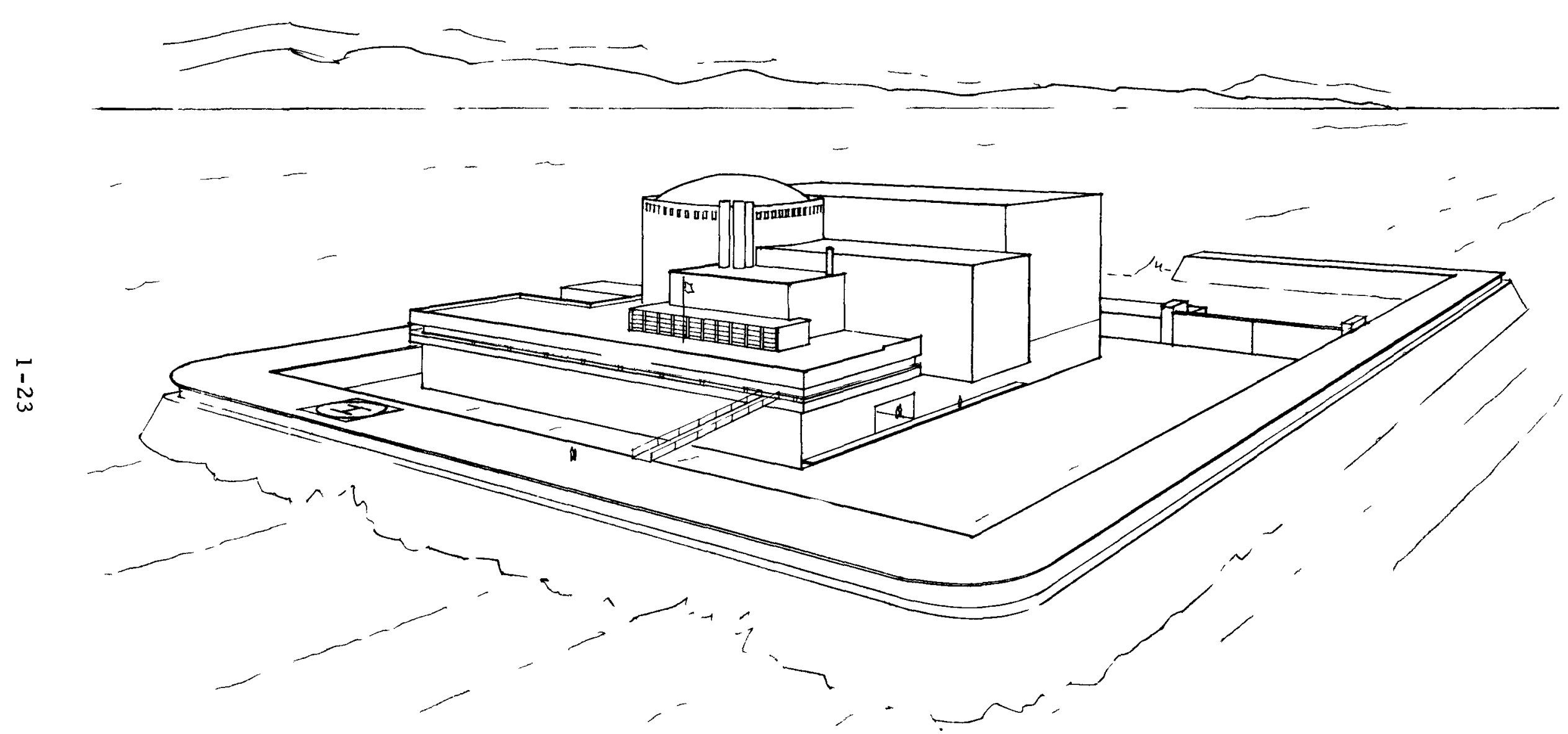

OFFSHORE - FLOATING SHALLOW 
12. Offshore-Floating Deep - The locations for offshore floating deep plants increase in number as a minimum water depth is no longer a constraint. Elimination of zones adjacent to populated areas or shallow water locations still provide a large number of potential sites. The prefabricated concept utilizes a ship hull as the platform since that shape results in less ocean forces acting on the structure while in its moored position in deep ocean water 3 miles from shore. No protective devices are included to preclude ship collision since such devices have not been developed nor are yet represented as feasible.

13. Offshore-Seabed - This concept is a plant contained in a large diameter, long concrete cylinder and hull shaped exterior to be located in water depths of 250 to 300 feet. The prefabricated vessel would be towed to the site and, by flooding, would be lowered into place. The facility would interface with the surface by several ventilation and access. shafts terminating on a large platform located above the maximum storm waves. The platform would be supported on the plant structure below.

14. Offshore-Undersea - An underground plant similar in concept to other underground plants in rock would be located in massive rock offshore. The undersea concept would be located in massive rock formations offshore. It is desirable to locate the facility about 3 miles offshore, but the access tunnel should be of sufficient length to permit a gradient suitable for vehicular traffic into the facility, possibly on rail, and the refore might have to be as long as 6 or 7 miles. However, this length can be provided by aligning the tunnel parallel or askew with the shore before turning to a position 3 miles offshore.

15. Offshore-Artificial Island - An aboveground plant similar to the facilities on a shallow water floating plant concept would be located on an artificial island offshore about one mile. As in the case of the floating plant in shallow water, the number of locations with depths of 40 to 60 feet are too limited at 3 miles from shore to be considered.

16. Offshore-Natural Island - An aboveground plant would be located on a low terraced shore of an island as exists in southern California. Santa Cruz Island is used as a candidate since it contains suitable topography although its seismic and other environmental characteristics are not necessarily favorable. 
17. Offshore-Tuned Sphere - The concept is a plant located in a prefabricated hemispherical concrete structure about 300 feet in diameter and higher than a hemisphere. Wave frequencies are tuned out to achieve stability by adjusting the water mass in a tank which would be supported over 200 feet above the deck.

\section{4 TRANSMISSION LINES}

Overland transmission lines can be grouped into three categories:

1. Overhead bare conductor.

2. Underground, insulated, single or multiconductor cable.

3. Aboveground, low profile, insulated, single or multiconductor cable.

The overhead bare conductor is the lowest in cost. However, it requires a large amount of right of way for towers and removal of surface effects and is vulnerable to lightning effects. Further, it is under considerable environmental impact scrutiny. It may be assumed that for future planning, overhead lines will be permissible only in sparsely settled or undeveloped areas, and that in developed communities high voltage underground lines will be required. Use of $345 \mathrm{kv}$ and higher voltage underground systems will be limited since that voltage is used predominantly in the outlying areas where overhead lines are not so objectionable.

Underground lines are presently installed in direct buried ducts in a number of locations, but these are lower voltage, low capacity lines making short road crossings. The large central station power plants now being planned require greater carrying capacities in the transmission lines to minimize their cost and environmental impact. Better insulation and use of forced cooling permit increases in capacity.

Oil cooled or compressed gas insulated systems appear to provide a possible solution for at least short runs in the future. Research and demonstration installations using sulphur hexafluoride $\left(\mathrm{SF}_{6}\right)$ as the insulator/coolant have shown that voltage levels through $500 \mathrm{kv}$ are feasible and could be economical for runs of several miles in length. The system has application to underground installations as well as aboveground low profile installations. By locating the lines aboveground, but at low profile, it is possible to reduce the cost by 
eliminating excavation, backfill, and corrosion protection required in buried systems. Large capacity lines longer than a few miles, as would be required by many future plants, now require that a number of lower capacity circuits be used, thus resulting in high cost.

There are a number of alternatives being developed for longer, larger capacity lines. Pipe-type cable may be able to carry as much as 1,200 Mw. Gas-dielectric or vacuum-insulated systems might carry 2,000 Mw. Cryogenic systems will probably be required for higher capacities. Supercooled lines using helium potentially have the ability to carry large loads. Another form of cryogenic cable is the superconducting type that also is being developed.

Resistive-cryogenic systems using liquid nitrogen and having much larger capacity than the other systems are now in research and development, and might be more practical because the liquid nitrogen coolant would be more available. This system would require intermediate stations, perhaps every few miles, at which points the liquid nitrogen temperatures would be maintained and the liquid pumped through the next increment. This system is being targeted for availability in the $1980^{\prime} \mathrm{s}$. It will be considerably higher in cost per mile than others in use, but its advantage is a far greater capacity that otherwise may not be possible, or may be possible only with a larger number of circuits which makes the total cost of the conventional system high.

Submarine high voltage lines are becoming of more concern because of plans to install floating power plants on the east coast and the need there for transmission lines to shore. Today, high voltage submarine lines in service in the eastern United States are pipe and oil filled types with short runs and low capacities. Therefore, use of more than one circuit would be required. However, there is no precedent for reliably locating and maintaining these lines in as much as 300 feet of water as may be required in California conditions. Connection details during construction may present the major problems, and in shallow water zones the system would have to be buried in the ocean bottom for safety from anchor dragging or scouring. Also, if distances between the plant and shore become too great, then underwater intermediate compressor stations may be required, and this would complicate the system.

It is seen that a number of transmission line alternatives are in various phases of development. However, it appears that with a demand for providing underground, low profile, or submarine high voltage lines with large carrying capacities, suitable systems can be made available in the time frame required. 


\subsection{SITING CONCEPTS EVALUATION}

Placed in the position of trying to choose between a profusion of sites, siting concepts, and energy sources, and subject to widely different interests and opinions, it is impossible to reach an objective decision without some scheme or formalism for organizing the issues and evaluating the options. Although the numerical values from such a scheme are open to question, it at least serves to focus the arguments and to reduce them to explicit terms. Therefore, a formalism was developed and evaluation of each siting concept made to arrive at a ranking or acceptability of each.

Currently, the evaluation factors used in selecting concepts or sites include feasibility, environmental impact, plant exposure, and nuclear safety, in addition to cost. The following are the factors which have been used in evaluating concepts in this study. Note that subfactors which are peculiar only to site selection and not to the concepts being evaluated are not included since they would contribute little in siting concepts evaluation. They would be meaningful only if specific sites were being judged for a particular concept. Also, considerations such as fission product ultimate disposal which present the same problem for any siting concept are not appropriate for consideration in the evaluation of alternative siting concepts.

1. Cost Factors

a. Capital costs and interest during construction.

b. Operation and maintenance costs.

c. Taxes, insurance, depreciation, and interim equipment replacement.

2. Environmental Impact

a. Compatibility with existing and planned adjacent land use.

b. Ability to return the site to its natural state at plant retirement.

c. Visual image.

d. Operations impact on physical and biological environment.

e. Construction impact on physical and biological environment. 
f. Multiple use of reject heat and facilities.

g. Multiple use of site property.

3. Feasibility

a. State of the art.

b. Existence of potential sites.

4. Risk
a. Plant exposure.
b. Safety and damage.

The measures of merit for each of the factors and their weighted values are discussed in the report. Each factor was assessed against each siting concept, and relative ratings were determined. The product of relative rating and factor weighted value becomes the contribution to the acceptability of a concept. The sum of all contributions is termed the acceptability of a concept.

The results of the evaluation of all factors including cost, environmental impact, feasibility and risk, considered applicable to assessing acceptability are presented in Table $1-1$ listing siting concepts in ranked order. A first look at ranking acceptability indicates that the inland plant has the greatest acceptability and that the other aboveground concepts, i.e., lagoon, hillside, low profile, and coastal plants have greater overall acceptability than the remaining concepts. The offshore floating plant in deep water is next and represents the most favorable offshore concept, assuming a ship collision risk is acceptable. The underground plant in poorly cemented materials appears to be the most acceptable of the underground concepts.

Although subject to seismic risk, the inland plant is reasonably higher in overall acceptability from a combination of lower cost, low environmental impact, and greater feasibility when compared to other concepts. The hillside plant has good acceptability due to low cost as well as average risk, environmental impact, and technical feasibility; but somewhat fewer potential sites are available than for the inland plant. Still fewer potential sites are available for aboveground coastal and low profile plants. The floating plant in an onshore lagoon has good acceptability considering risk, principally due to its lower seismic risk and the elimination of ship collision which confronts most of the offshore concepts. 
TABLE 1-1

CONCEPT TOTAL ACCEPTABILITY VALUES

\begin{tabular}{|c|l|c|}
\hline $\begin{array}{c}\text { Concept } \\
\text { Number }\end{array}$ & \multicolumn{1}{|c|}{ Title } & $\begin{array}{c}\text { Acceptability } \\
\text { Values }\end{array}$ \\
\hline 2 & Aboveground-Inland & 0.779 \\
5 & Aboveground-Floating, Lagoon & 0.761 \\
3 & Aboveground-Hillside & 0.756 \\
4 & Aboveground-Low Profile & 0.674 \\
1 & Aboveground-Coastal & 0.657 \\
12 & Offshore-Floating, Deep & 0.649 \\
9 & Underground-Nonmassive, Poorly & 0.642 \\
15 & Cemented Materials & 0.637 \\
11 & Offshore-Artificial Island & 0.636 \\
17 & Offshore-Tuned Sphere & 0.617 \\
7 & Underground-Massive Sedimentary Rock & 0.603 \\
16 & Offshore-Natural Island & 0.581 \\
14 & Offshore-Undersea & 0.549 \\
6 & Underground-Massive Igneous Rock & 0.540 \\
8 & Underground-Unconsolidated Materials, & 0.522 \\
13 & Beach & 0.502 \\
10 & Offshore-Seabed & 0.494 \\
\hline
\end{tabular}


The underground concept generally have lower acceptability than the aboveground plant from a cost standpoint, with the concept in unconsolldated sodiments at a beach site being the least acceptable. The concepte in poorly cemented materials and in sedimentary rock have greater feasibility due to the existence of more potentially sultable sites, and this contributes to their greater acceptability than the other underground concepts.

Of the offehore concepts, the artificial island and floating platforms are more acceptable. The contributing factor appears to be feasibility as compared with the other offshore concepts. The artificial island and floating platform in shallow water are closer to the shore than the others. If constrained to a 3 -mile limit, their feasibility drops for lack of potential sites in California.

The least acceptable of the offshore concepts is the seabed version, mostly because of the high seismic and ship collision risk and the low technical feasibility.

The merit of these acceptability interpretations can be further analyzed by assessing acceptability as a function of some of the individual evaluation factors. It can be said that concepts which appear more acceptable in each of these plots are more acceptable on an overall basis regardless of weighted values that might be given to each of the evaluation factors. Acceptability was measured against cost, environmental impact, feasibility, and risk. Assessments were also made against the measurable subfactors (visual image and miles of potential coastal sites).

Bus bar costs including capital, operating, and maintenance cost estimates for each concept are presented in Table 1-2, considering a fixed rate charge of 15 percent and using 1972 costs. From a cost standpoint, the inland plant, hillside, and floating lagoon concepts rank high. Least bus bar costs are observed for the aboveground coastal and low profile concepts, but they are less acceptable than the other aboveground facilities with respect to the other three factors. With respect to the coastal plant, the cost penalty for an inland plant is about 9 percent and for the hillside plant located within $1-1 / 2$ miles of the coast is about 4 percent greater than the coastal concept, based on bus bar costs. The underground cut-and-cover concept is the more acceptable overall of the underground concepts; bus bar costs for it and the other underground concept in massive igneous or sedimentary rock are about 
TABLE 1-2

\section{BUS BAR COSTS *}

Concept

Aboveground - Coastal

Aboveground - Low Profile

Aboveground - Hillside

Aboveground - Inland

Aboveground - Floating, Lagoon

Underground - Massive Sedimentary Rock

Underground - Massive Igneous Rock

Offshore - Artificial Island

Underground - Nonmassive, Poorly Cemented Materials

Offshore - Floating, Deep

Offshore - Natural Island

Offshore - Seabed

Underground - Massive Rock, Faulted

Offshore - Floating, Shallow

Offshore - Tuned Sphere

Underground - Unconsolidated Materials, Beach

Offshore - Undersea
Mils/Kw-Hr

8.86

8.87

9.18

9.65

9.91

10.25

10.25

10.35

10.39

10.48

10.51

10.96

11.30

12.01

12.06

12.96

13.20

*Includes investment, operation, maintenance and fixed rate charge of 15 percent. 
16 percent higher than the coastal plant $(20$ percent higher based on capital costs). The most costly concepts are the underground plants at $a$ beach site and the undersea location.

Evaluating total acceptability against cost acceptability, or low cost, Figure 1-7, which shows increasing acceptability by increasing values along both axes, presents the more favorable concepts in the upper right-hand portion of the plot. Furthermore, the more favorable concepts with respect to the isolated factor (cost) shown on the abscissa appear on the right side of the plot. Figure 1-7 indicates that all five aboveground concepts which are highest in overall acceptability appear in the most favored zone when viewed on a cost basis. The aboveground hillside concept appears to be the most favorable of these.

Similar plots of total acceptability versus environmental impact, feasibility, or risk indicate the aboveground concepts are in the favored zone.

When evaluating feasibility, the land-based aboveground concepts rank high in technical feasibility because similar plants are now functional. The floating plants in shallow water and the plant on an artificial or natural island also rank high when considering the state of the art. Underground plants and the other offshore concepts (deepwater) are less feasible because of a lack of experience or lagging stages of development.

In assessing feasibility of a concept, it is also necessary to consider the extent to which sites conducive to the concept can be identified. The greater the number of potential sites, the greater the potential use of the concept and, therefore, the greater the feasibility. The availability of suitable environments is not included in this evaluation since that will be dependent on ownership, interventions, time, and many other factors. However, a reasonable measure of merit is the mileage of suitable coastline which might be made available in California for each concept. These are seen on Plate 1-1 and tabulated in Table 1-3 (miles of inland sites are normalized to the same base as coastal sites by dividing the potential inland area shown on Figure $1-2$ by an equivalent coastal zone width of $1-1 / 2$ miles).

In some cases, there are many more miles of suitable site characteristics than needed to meet planning requirements. There are upper limits of availability beyond which added coastal mileage 


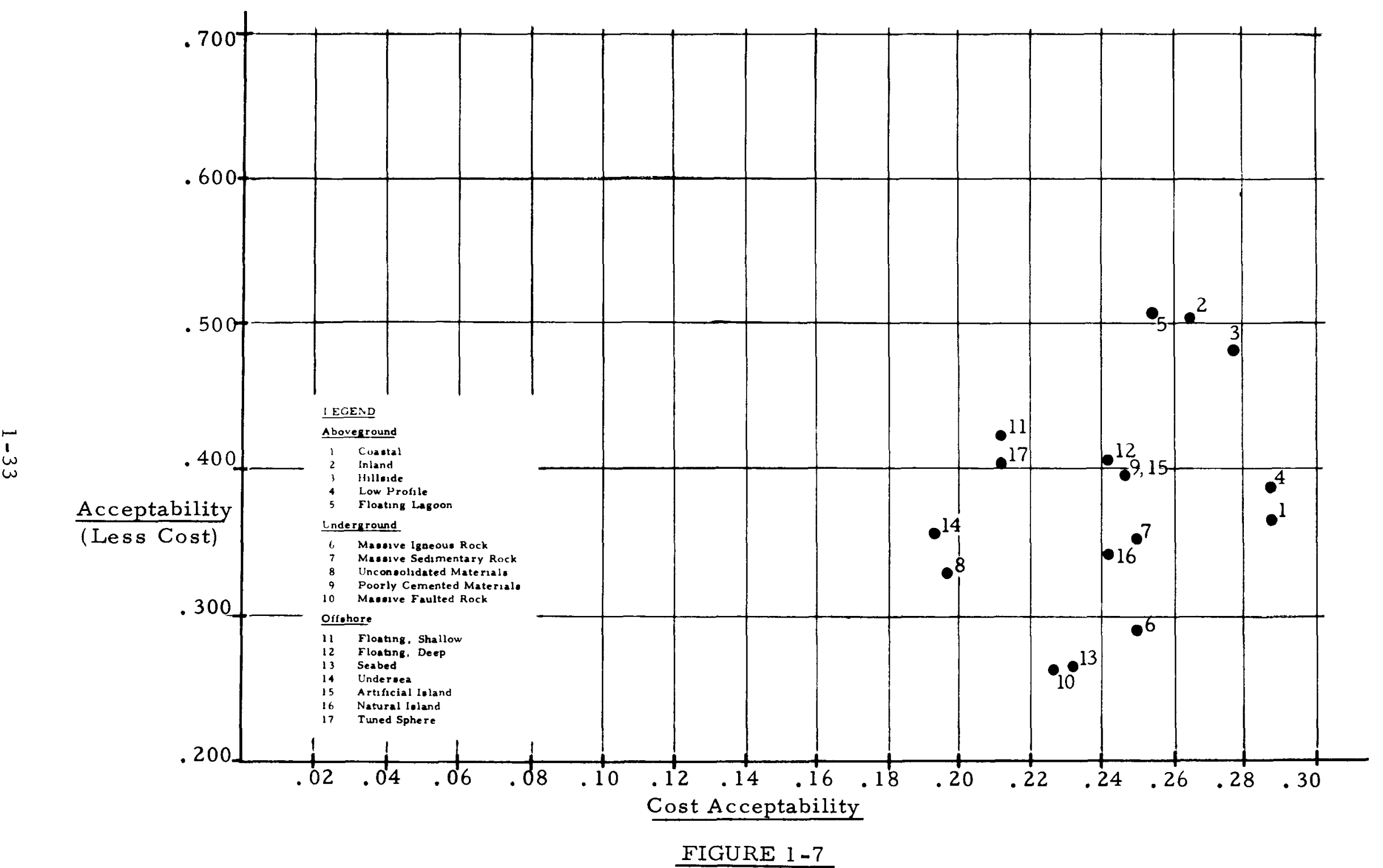

COST EVALUATION 


$\begin{array}{lc}\text { Aboveground - Inland } & 20,000 * \\ \text { Offshore - Floating, Deep } & 855 \\ \text { Offshore - Tuned Sphere } & 855 \\ \text { Offshore - Floating, Shallow } & 580 \text { *** } \\ \text { Offshore - Artificial Island } & 580 * * \\ \text { Aboveground - Hillside } & 408 \\ \text { Underground - Nonmassive, Poorly Cemented } & 265 \\ \text { Aboveground - Coastal } & 144 \\ \text { Offshore - Seabed } & 135 \\ \text { Aboveground - Low Profile } & 119 \\ \text { Aboveground - Floating, Lagoon } & 115 \\ \text { Offshore - Undersea } & 102 \\ \text { Underground - Massive Sedimentary Rock } & 96 \\ \text { Underground - Unconsolidated Materials, Beach } & 69 \\ \text { Underground - Massive Rock, Faulted } & 29 \\ \text { Underground - Massive Igneous Rock } & 6 \\ \text { Offshore - Natural Island } & 2\end{array}$

* Equivalent coastalmiles@1-1/2 mile width.

*** Within 1 mile from shore (other offshore concepts at 3 miles, plus). 
does not proportionately increase the concept feasibility. Also, assuming that 25 sites might be required by 1990 , with each site requiring as much as 2 miles of coastline (for six $1,100 \mathrm{Mw}(e)$ units), concept feasibility should diminish very rapidly if less than 100 miles of coastal environment acceptable to the concept is identified, considering that many sites may be unacceptable for other reasons.

Considering the number of potential sites, the inland plant ranks highest. Hillside plants also rank high because of a high percentage of hilly terrain available in California. If offshore plants can be located within a mile or so offshore, the floating plant and artificial island concepts in shallow water have a great number of sites available, as do the deepwater floating concepts.

Seismic activities for land-based concepts and ship collisions for offshore concepts constitute the greatest hazards or risk associated with the siting concepts. Since the floating platform in a lagoon tends to be protected to some degree from both events, it is particularly acceptable with respect to risk. The other concepts in order of increasing risk are the other aboveground concepts, the underground, and offshore groups.

If visual image is to be the key evaluation factor, then distant offshore natural island, undersea, and hillside locations are the highest ranked.

\subsection{ALTERNATIVE SYSTEMS EVALUATION}

When considering nuclear power systems alternative to the light water reactor, such as the high temperature gas cooled reactor with a steam cycle or the liquid metal fast breeder reactor, there is no apparent effect on the relative ranking of the concepts described above. It is most likely that the effects would be proportional for each factor with respect to concepts using the light water reactor power system.

When considering fossil-fueled plants as an alternative to the light water reactor systems, the large exhaust stacks and fuel storage requirements are either not feasible for incorporation in many of the siting concepts considered, or they would require additional concept definition beyond the scope of this study. The same is true of various cooling systems as applied to many of the siting concepts since the inland plant appears to be one of the more acceptable concepts 
in the base line studies, but may present a water availability problem, several variations of an inland plant using a dry cooling tower were considered. Mechanical draft towers could be used in the dry cooling concept, but since natural draft towers were assumed when evaluating the basic inland concept with wet cooling, the natural draft tower also was assumed for the evaluation of the inland concepts using dry cooling.

Evaluations of an inland plant using dry cooling towers were made for plants, each using an LWR system and a low sulphur content fossilfueled steam supply system, and one using a high temperature gas reactor with a gas turbine. The latter is now being studied and has not yet reached the development stage. The results of the evaluations indicate that for the cost, environmental impact, feasibility, and risk factors considered, all three concepts have acceptability similar to an inland plant using a wet cooling tower and, therefore, also are viable alternatives to the coastal plant. The evaluations did not consider the potential adverse atmospheric and terrestrial effects resulting from use of the fossil-fueled plants, nor did it quantify the potential savings in water resources provided by all three approaches. However, the latter would tend to increase the acceptability of these solutions.

\subsection{CONCLUSIONS}

In summary, it can be concluded that:

1. The inland siting concept ranks highest in overall acceptability and would utilize land of greatest abundance in California. The concept consistently ranks high in acceptability when compared with other concepts against only cost, environmental impact, feasibility, or risk individually. Not fully investigated is the availability of wate $r$ for inland plants, but the potential use of dry cooling towers may reduce that constraint. The other concepts which also rank high are coastal zone aboveground plants located in a hillside environment and the floating platform-mounted plant in a lagoon environment at the shore. The California coast has a predominance of hilly areas potentially suitable for the hillside concept. Significantly fewer sites exist for the lagoon concept. The lagoon concept is particularly dependent on the existence of sites having low topographic features, as well as acceptable environmental impact, both site dependent. The existence of such sites must be more fully investigated to prove the high acceptability ranking of this concept.

2. Underground concepts are not competitive with the acceptability of aboveground plants; but if they are preferred for aesthetics or for any of the other factors studied, the 
underground concept appearing most favorable is one located in a cut-and-cover situation in nonmassive or poorly cemented materials. This is mainly due to the larger number of potential sites in this media.

3. Offshore concepts are not competitive with the acceptability of aboveground plants. However, some concepts are more acceptable than underground concepts. The floating plant in a vessel located in deep water is more acceptable than the other offshore concepts because of its lower cost and the length of coastline where deep water exists. However, high rank is predicted on accepting the risk of a ship collision. If avoidance of a ship collision cannot be assured, the floating platform in a breakwater or the plant on an artificial island are more acceptable solutions. For these concepts, the plant must be located in shallow water as close as one mile to shore, since an insufficient number of shallow water sites exist at greater distances.

\subsection{RECOMMENDA TIONS}

As a result of the study and the conclusions noted above, a number of specific recommendations are made. Action toward these recommendations might best be implemented by Federal or State Governments; by the utility companies most directly concerned; or in some cases, by the nuclear steam supply system manufacturers. No specific directions are given nor intended.

\subsubsection{Sites and Planning}

1.8.1.1 Inland Plant Plan. Recognizing the advantages in siting power plants inland, but noting the limited supply of cooling water in many inland areas of California, develop a plan designating regions which may be suitable for such plants. Modify the State water resource and transmission plan to include makeup water for evaporative cooling systems used in conjunction with power plants.

1. Study the potential development of plant locations near present aqueduct systems which presently supply large quantities of water for irrigation purposes. Consider the potential for rerouting irrigation water into once-through cooling systems in some plants to be located upstream of irrigation areas. Discharge water would be 
cooled by evaporation while flowing to the downstream irrigation systems. (Increased evaporation of this water will result from higher water temperatures in the aqueduct.)

2. Consider the alternative of developing new water sources and water transmission systems to regions where power plants potentially might be located.

3. Consider a combination of these approaches to satisfy the development time frame.

4. Consider the potential location of inland plant sites at existing hydro projects which contain dammed reservoirs and which have too low a power generation capacity or are inefficient as compared with current power generation plants. These reservoirs could serve to feed makeup water to evaporative cooling systems, or might be sufficiently large to constitute an evaporative lake.

1.8.1.2 Water Allocation Study. Review existing water rights and allocations from the California Water Plan. Assure the utilization of this water and the potential for reassigning rights for power plant cooling purposes if shown to be in the best overall interest of the State.

1.8.1.3 Seismic Intensity Maps. A principal factor in seeking nuclear power plant sites in California is the avoidance of areas with high seismic risk. The magnitude of seismic activity at any location is based on the seismic history of the area under consideration and of adjacent areas. Fault maps exist and general plots show contours of seismic intensity. However, a study should be accomplished in which, based on known faults and historic seismic intensities in coastal and relatively flat inland a reas, predicted intensities a re determined and microzonation grid maps are prepared to indicate these values as an aid in plant siting.

1.8.1.4 Hillside Topographic Study. Aboveground coastal hillside locations appear acceptable for power plant sites. These sites generally are located on the inland side of the coastal road, and it 
is desirable to validate the existence of suitable topography in greater detail than was possible in this study. Such investigations may tend to increase or decrease the potential availability of suitable sites.

1.8.1.5 Lagoon Topographic Study. If it can be ascertained that floating platforms in an onshore lagoon would be publicly acceptable, then conduct a detailed investigation to determine the existence of suitable topography in low population zones to increase the accuracy of the limited investigation made in this study.

\subsubsection{Siting Concepts}

1.8.2.1 Hillside Concept Study. Validate cost estimates and other factors for the hillside plant by preparing a concept study based on a potentially. acceptable site.

1.8.2.2 Preferred Underground Concepts. Incentives may be generated for locating plants underground because of factors not considered in this study. In that case, concepts which should be given greater consideration are those underground in nonmassive, poorly cemented materials or in massive, sedimentary rock since more coastal sites with these materials exist in California than the other materials studied. The problems which may be associated with mining in a sedimentary rock and the development of a detailed quality design concept appear greater than in the cut-and-cover approach in poorly cemented materials. Therefore, investigate the potential problems which might be encountered in excavating and supporting massive sedimentary rock in California and thereby validate the cost estimates, feasibility, and risks used in this study.

1.8.2.3 Seismic Evaluation of Floating Platform in Lagoon. One of the principal advantages anticipated in the use of a floating platform supported plant in a lagoon is the assumption of lower seismic risk. Detailed studies to determine the reality of this assumption a re lacking. Perform a conceptual seismic analysis of a floating plant moored in an enclosed shallow water environment, to determine the impact of seismic activity on the floating body.

1.8.2.4 Floating Plant Fabrication Facilities. One of the constraints in considering floating platform-mounted plants is the question of providing fabrication facilities on the west coast, or the practicality of towing plant modules here from the east coast. Therefore, investigate the practicality of supplying such plants on the west coast. 


\subsubsection{Dry Cooling Systems}

1.8.3.1 Dry Cooling Towers. The use of dry cooling towers for inland plants where water is not readily available appears to be a reasonable alternative to wet towers, considering cost and environmental impact. However, demonstration is needed to establish feasibility in the sizes required for large central station plants. Since this concept represents a means of reducing the requirement for large quantities of water as a constraint in siting inland plants, demonstration projects requiring smaller units should be initiated and then project sizes increased on subsequent larger plants so that feasibility can be established.

1.8.3.2 HTGR Development with Gas Turbine and Dry Cooling Systems. The application of a high temperature gas cooled reactor system with a gas turbine provides an opportunity for reducing the strain on a limited water supply which often is characteristic of inland sites. The high temperature heat discharged from this system has a greater difference from ambient temperatures and thereby provides a greater efficiency and a more economical dry cooling tower system than afforded by the thermal transfer from closed loop steam systems. Efforts to develop the gas turbine and dry tower peculiar to the HTGR system should be encouraged.

\subsubsection{Risk Assessments}

Risk evaluations made for this study are dependent on the frequency of occurrence of the postulated natural or man-made events which cause the risk. Data on the frequency of these events are inadequate. Existing data are of uncertain meaning in regard to evaluating siting concepts and even less data a re available for evaluating specific sites. Refinements in risk assessments may affect ranking of concepts. It is recommended that a more detailed risk analysis be performed on the most favorable siting concepts from each of the three basic groups: aboveground, underground, and offshore. The analysis should include a detailed investigation of potential mitigation systems and frequency of occurrence of events. 


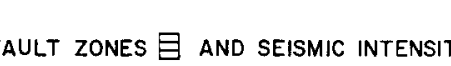

HOMBOLT

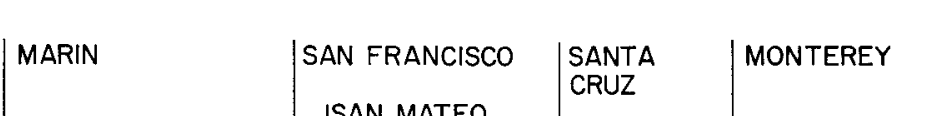

GEOLOOY

MASSIVE IGNEOUS Rock_

MASSIVE SEDMMENTARY ROCK

UNCONSOLDATED SEDIMENTS

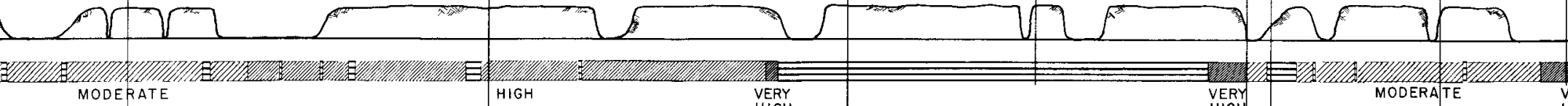

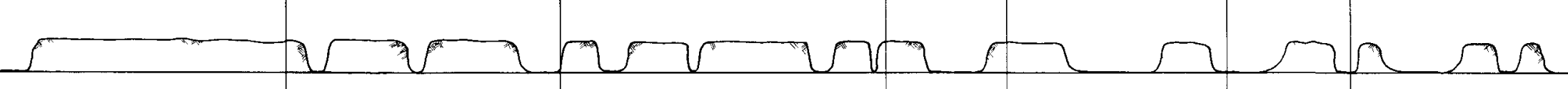

TER Matenals

界品

E

LAND USE
POPULATE

$\equiv$

AGRICULTURAL

cascent

UNDEVELOOPED _ _

ARCHAELOOIC AND HISTORIC

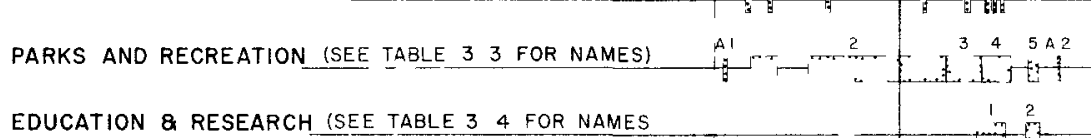

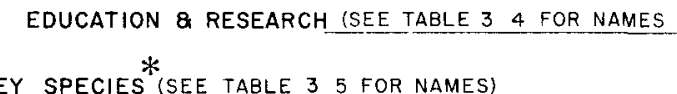

CANDIDATE AREAS (LOW POPULATION SHADED)

ABoveground CONCEPTS
BEACH OR LOW TERRACE

HLLLY оR RugG

LAGOON

MASSIVE IISEEOUS ROCK, HLLLY

MASSIVE SEOIMENTARY ROCK, HLLYY

UNCONSOLDATED MATERALLS, BEACH_

MON-MASSIVE OR POORLY CEMENT

OFFSHORE CONCEPTS
SHALLOW WATER

SHALLOW WATER (40-60 FEET) GLOE IN

1N

inters

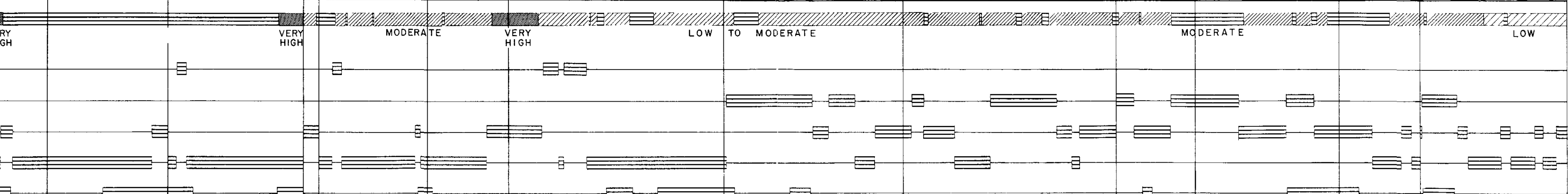

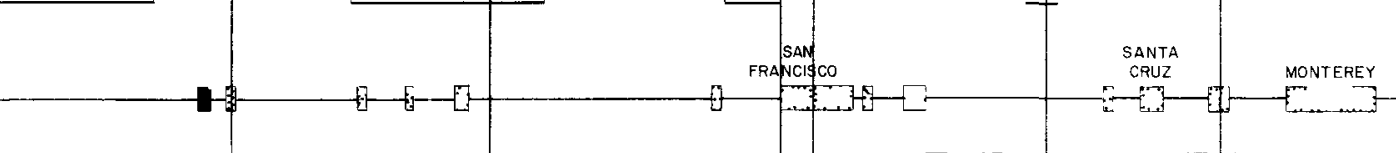

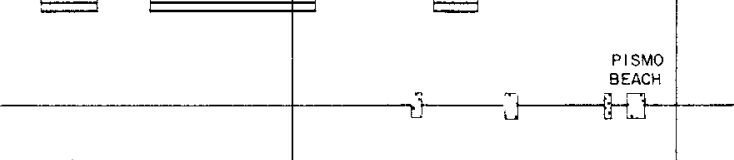

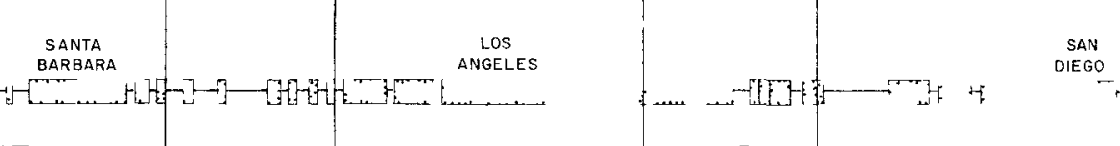

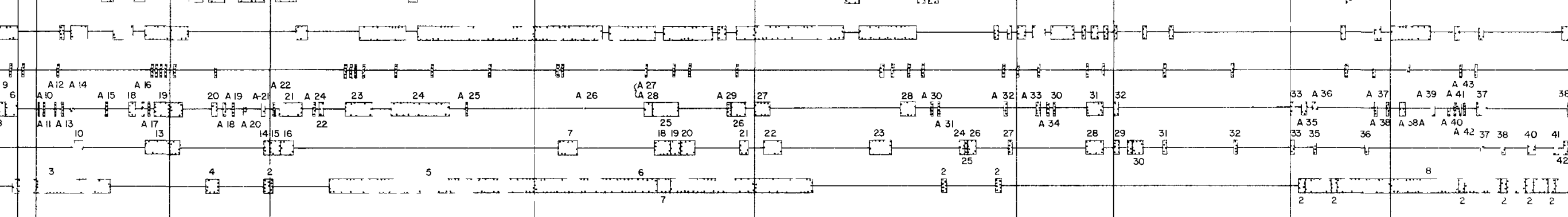
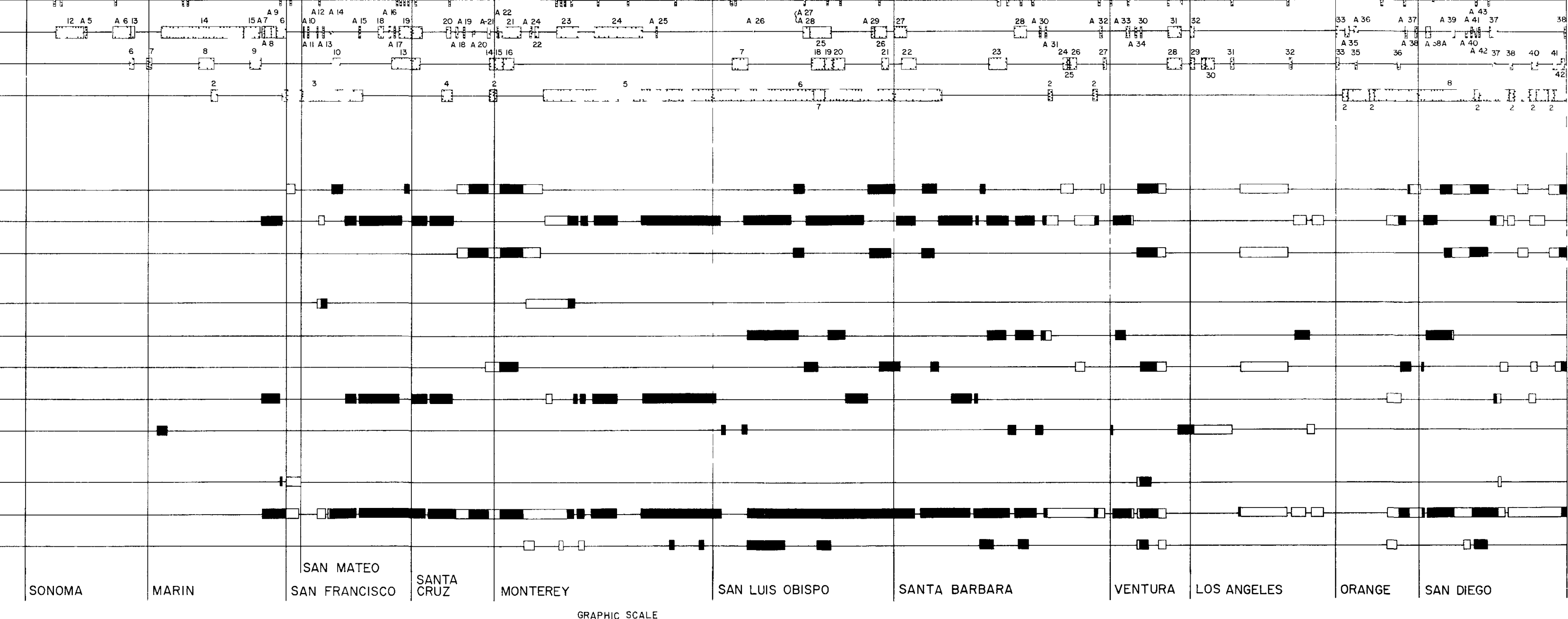


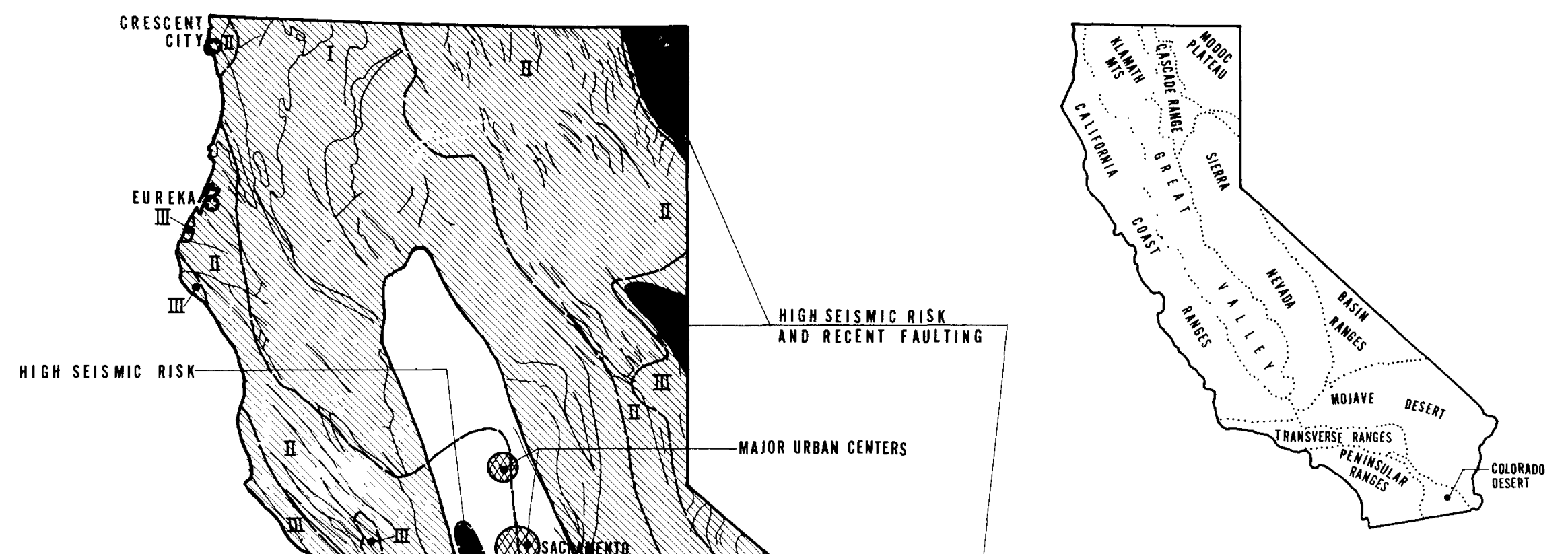

\section{NATURAL PROVINCES}
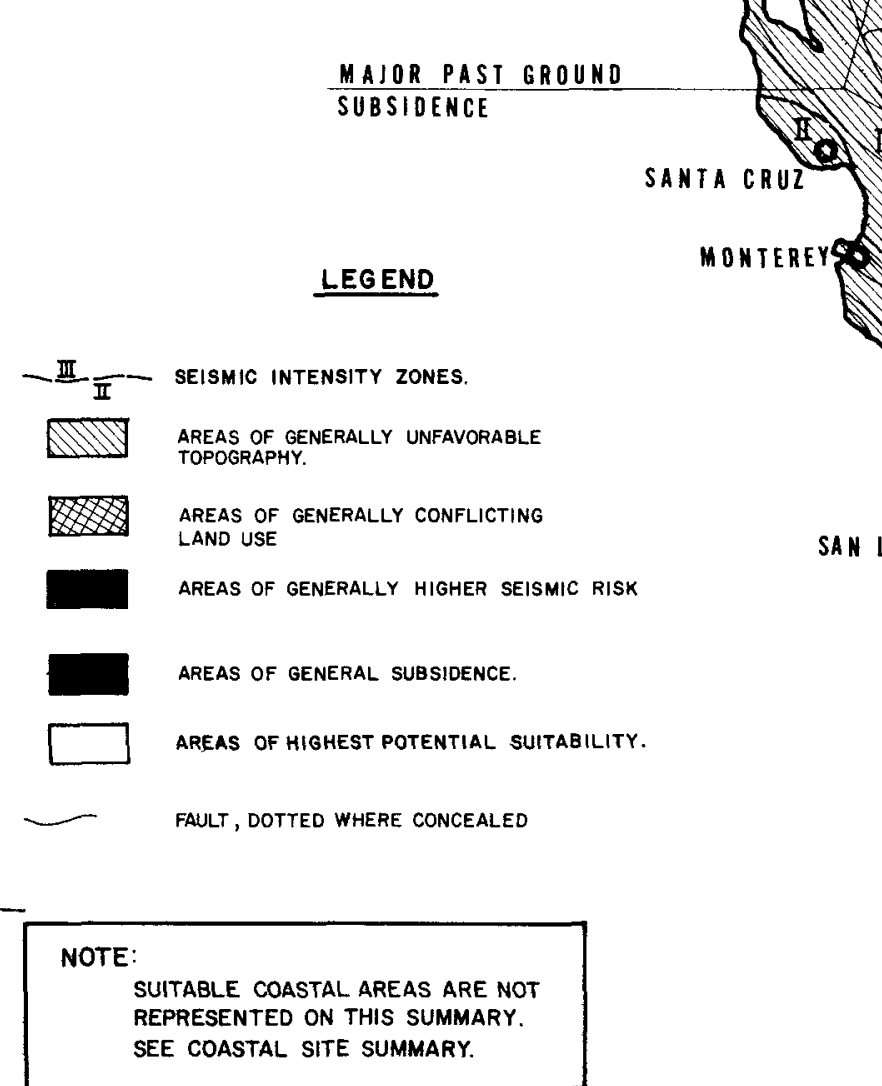


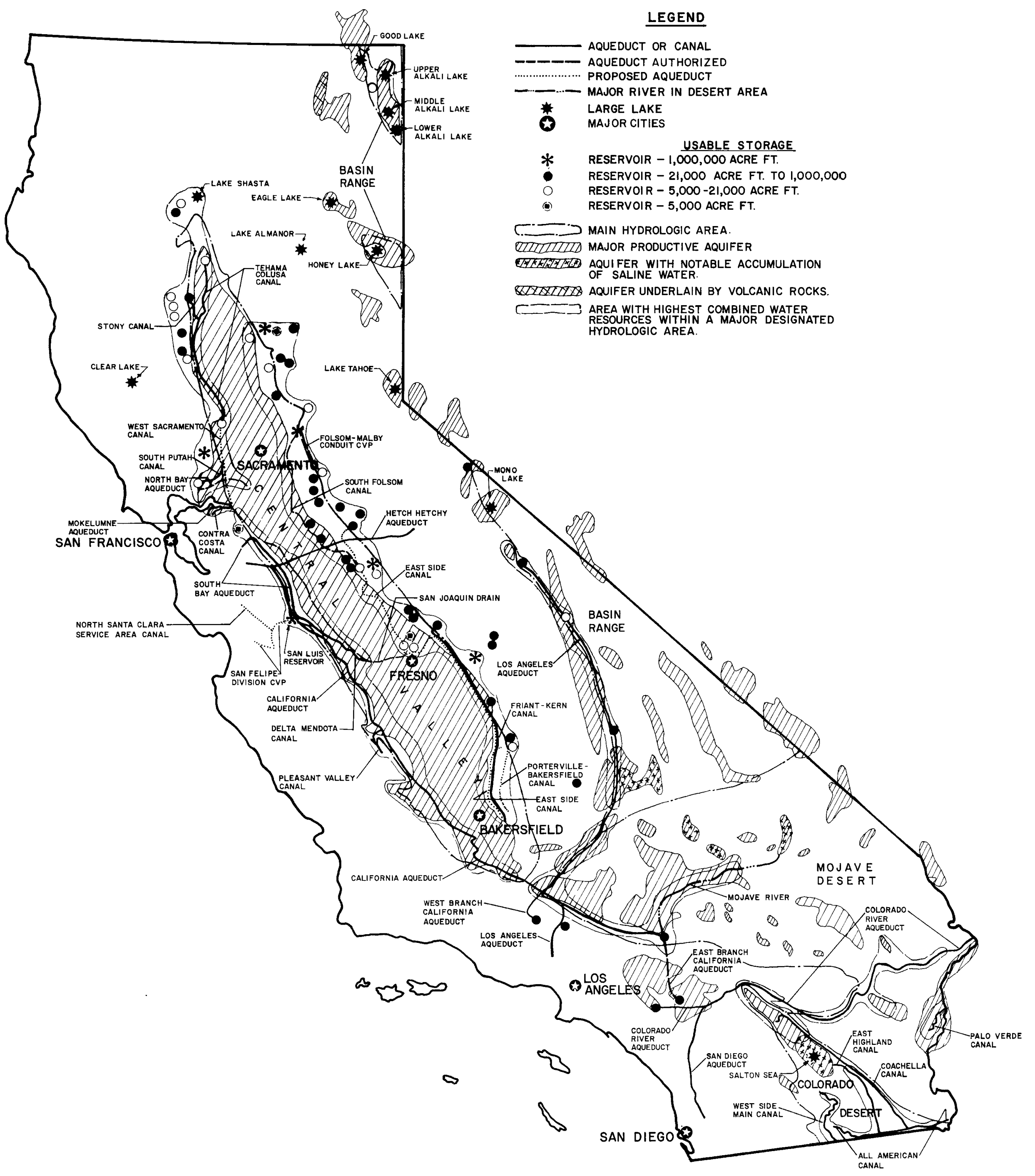

